Review

\title{
Lithium and lithium ion batteries for applications in microelectronic devices: A review
}

\author{
Yuxing Wang a, ${ }^{\text {, B B Liu }}{ }^{\text {a, }}{ }^{\text {, Qiuyan Li }}{ }^{\text {a }}$, Samuel Cartmell a , Seth Ferrara a , \\ Zhiqun Daniel Deng ${ }^{\text {b, }}$, Jie Xiao ${ }^{\text {a, * }}$ \\ a Electrochemical Materials and Systems Group, Energy and Environment Directorate, Pacific Northwest National Laboratory, Richland, WA 99352, USA \\ ${ }^{\mathrm{b}}$ Hydrology Technical Group, Energy and Environment Directorate, Pacific Northwest National Laboratory, Richland, WA 99352, USA
}

\section{H I G H L I G H T S}

- Chemistry and electrochemistry in lithium-based microbatteries.

- Recent concept and cell design towards different applications.

- Future perspectives of microbattery development.

\section{A R T I C L E I N F O}

\section{Article history:}

Received 4 February 2015

Received in revised form

9 March 2015

Accepted 26 March 2015

Available online

\section{Keywords:}

Lithium microbattery

3D design

Materials selection

Thin-film

Review

\begin{abstract}
A B S T R A C T
Batteries employing lithium chemistry have been intensively investigated because of their high energy attributes which may be deployed for vehicle electrification and large-scale energy storage applications. Another important direction of battery research for micro-electronics, however, is relatively less discussed in the field but growing fast in recent years. This paper reviews chemistry and electrochemistry in different microbatteries along with their cell designs to meet the goals of their various applications. The state-of-the-art knowledge and recent progress of microbatteries for emerging micro-electronic devices may shed light on the future development of microbatteries towards high energy density and flexible design.
\end{abstract}

() 2015 Published by Elsevier B.V.

\section{Introduction}

\subsection{Overview of lithium and lithium ion batteries and need for micro-sized batteries}

High energy lithium and lithium ion batteries are playing a key role in the advent of the information age and will continue to expand their applications in many different aspects in the foreseeable future [1]. Batteries based on lithium chemistry are categorized in two groups, primary batteries and secondary (rechargeable) batteries. For primary batteries, metallic lithium is directly adopted as the anode whereas a variety of cathode

\footnotetext{
* Corresponding authors.

E-mail addresses: Zhiqun.deng@pnnl.gov (Z.D. Deng), Jie.Xiao@pnnl.gov (J. Xiao).

${ }^{1}$ The authors have contributed equally to the work.
}

materials have been used including manganese dioxide [2], carbon fluoride $\left(\mathrm{CF}_{\mathrm{x}}\right)$ [3], and silver vanadium oxide (SVO) [4]. A typical secondary lithium battery, or so called lithium-ion battery employs intercalation compound such as graphite as the anode. Cathode side also uses intercalation materials such as lithium cobalt dioxide $\left(\mathrm{LiCoO}_{2}\right)$, while $\mathrm{Li}^{+}$ions transport back and forth between cathode and anode during operating [5]. The most commonly used electrolyte is $\mathrm{LiPF}_{6}$ dissolved in EC/DMC [6,7]. Depending on the specific application, the solutes and solvents can be tuned to meet energy/ power ratio and operation temperature requirements.

Compared to other battery chemistries, lithium chemistry provides much higher power and energy densities in both gravimetric and volumetric terms [8], which are the most important parameters for applications in portable electronics such as smart phones, digital cameras and laptops. In addition, many lithium batteries have lower self-discharge rates and hence longer shelf lives. There has been a strong drive for vehicle electrification by using lithium 
ion battery technologies (LIBs) and several models of commercial PHEVs and EVs have hit the markets. In recent years, with the continuous cost reduction, lithium ion batteries become highly competitive to the aqueous redox flow batteries for large-scale (grid) energy storage applications.

The most common commercial LIBs used in the aforementioned applications are in the forms of cylindrical cells, pouch cells or coin cells. These batteries are generally bulk in size. For instance, the 18650 cylindrical cell is $65.2 \mathrm{~mm}$ long and $18.6 \mathrm{~mm}$ in diameter. The smallest coin cell (ML421) is about $5 \mathrm{~mm}$ in diameter. A much less discussed area of lithium-based batteries is microbatteries. The rapid development of electronic and information technology towards the directions of multifunctionality, high integration and high power drives the electronic devices towards miniaturization [9]. Lithium microbatteries are the ideal energy storage devices for biological/medical devices (pacemaker, hearing aid, defibrillator, in vivo imaging, etc.) [10] and self-powered microelectronics (miniature transmitters, sensors, actuators, etc.) [11]. These devices are sometimes on the millimeter scale or less (Fig. 1). Unfortunately, commercial coin cells are still routinely used in these applications due to the lack of commercial cells of smaller sizes so the reduction in size and the improvement in the capability of microsystems are presently limited by the size, capacity and power of their on-board power supplies. To bridge the gap, scientists at Pacific Northwest National Laboratory (PNNL) recently developed micro-sized lithium primary batteries with high energy density for Juvenile salmon acoustic telemetry system (JSATS) [12]. Panasonic commercialized industry's smallest pin-type batteries (bottomright figure in Fig. 1) with similar design in 2014 for targeted applications in wearable devices, electronic pens and medical devices [13]. These batteries combine small sizes and high specific capacity (Table 1) and hence are positive signs of progress in the microbattery field to meet short-term goals. The long-term goal of microbattery research will likely be defined by the fast growth of microelectromechanical systems (MEMS) technology that demands for even higher power, higher energy on a smaller scale [14]. Similar to bulk-size batteries, lithium microbatteries can be either primary or secondary. As the microbatteries in most applications are difficult to service (for instance, replace), the rechargeability can effectively increase the service life of a battery. Ultimately, service-free, continuously-powered devices may be realized through a combination of micro energy harvesting systems and rechargeable microbatteries.

\subsection{Traditional batteries for micro-applications}

Bulk-size lithium ion batteries normally consist of composite electrodes and liquid electrolytes. As the size of the battery shrinks, the fabrication process for composite electrodes and the use of liquid electrolyte become increasingly incompatible with the required microfabrication process. The parasitic weight in the downsized batteries also increases at the same time. As a result, microbatteries differ greatly from bulk-size LIBs in their architecture design and material choices. Since the composite electrode design works well with a wide range of electrode materials, the research focus of bulk-size batteries is on materials development, i.e. optimizing the electrochemical couples, improving the stability of electrolytes and developing new lithium chemistry (lithium sulfur, Si anode, etc.) $[8,15,16]$. For microbattery research, the focus is more on innovative fabrication procedures and novel architectures of electrodes or full cells [17-19].

Thin-film batteries adopting two-dimensional (2D) planar design are the most popular traditional batteries for microapplications. An individual cell consists of thin, dense layers of battery components fabricated by various deposition methods (Fig. 2a). The operating principle of thin-film batteries is similar to bulk-size batteries with composite electrodes, except that the diffusion paths are much shorter. Since only active (electrode) materials are used in the electrode layers (in contrast to composite electrodes in bulk-size cells), the electronic and ionic conduction within the electrodes are entirely dependent upon the intrinsic properties of electrode materials. As a result, the thicknesses of electrodes are limited to a few microns to avoid loss of power and poor electrode utilization. For the electrolyte layer, solid-state

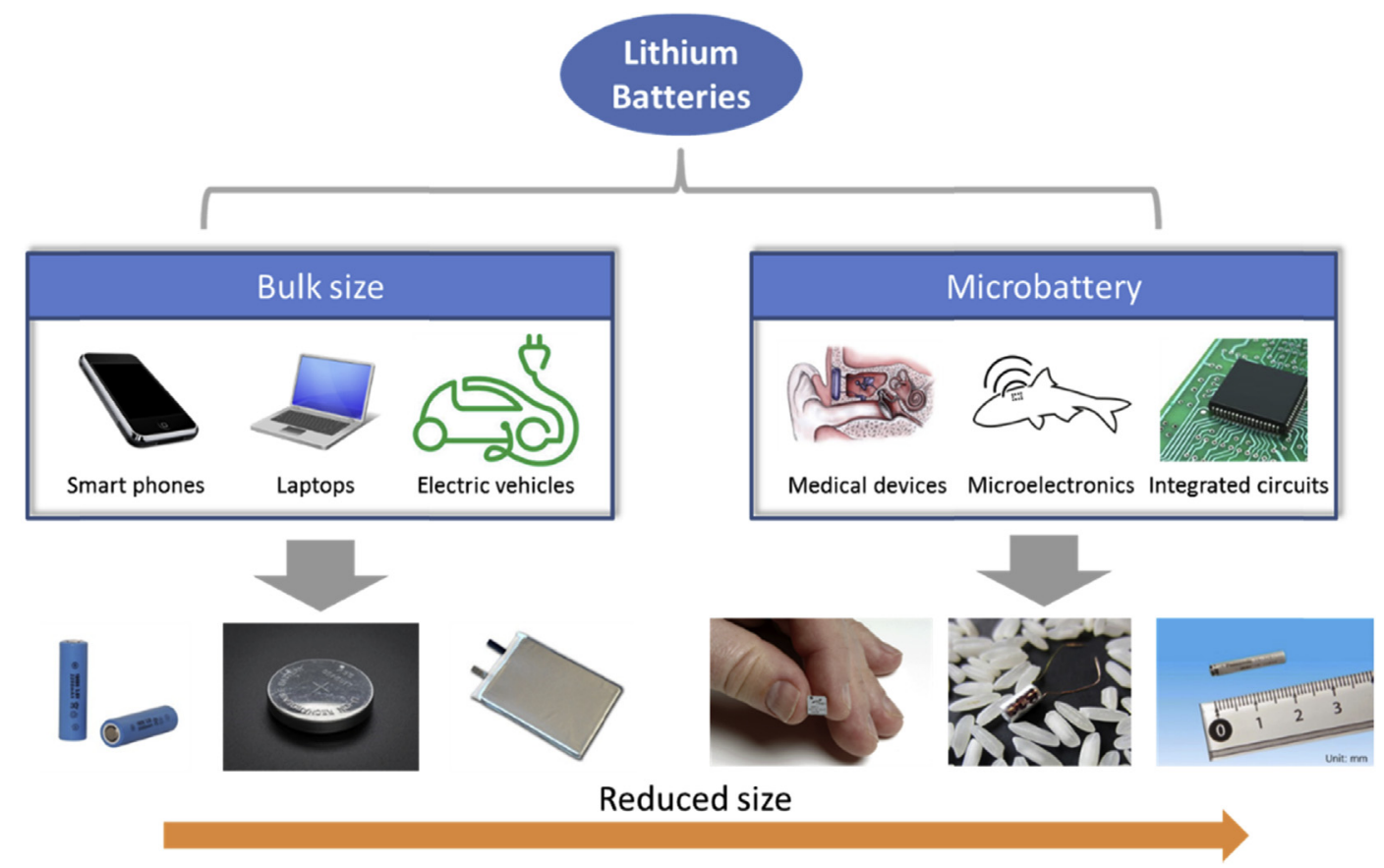

Fig. 1. Examples of lithium battery applications and the form of cells used. 
Table 1

A comparison of sizes and energy densities of different lithium batteries.

\begin{tabular}{|c|c|c|c|c|c|}
\hline & Type & Volume $\left(\mathrm{mm}^{3}\right)$ & Maximum dimension (mm) & Specific capacity $\left(\mathrm{Wh} \mathrm{L}^{-1}\right)$ & Chemistry \\
\hline NCR18650, Panasonic [29] & Cylindrical; Secondary & 16700 & 65 & 577 & Lithium-cobalt \\
\hline CR2032, Panasonic [33] & Button; Primary & 1000 & 20 & 675 & $\mathrm{Li} / \mathrm{MnO}_{2}$ \\
\hline ML421, Panasonic [32] & Button; Primary & 38 & 4.8 & 95 & $\mathrm{Li} / \mathrm{MnO}_{2}$ \\
\hline MEC201, Thinergy [31] & Thin-film; Secondary & 110 & 25.4 & 36 & $\mathrm{Li} / \mathrm{LiCoO}_{2}$ \\
\hline CBC005-BDC, Enerchip [30] & Thin-film; Secondary & 0.75 & 2.25 & 27 & $\mathrm{Li} / \mathrm{LiCoO}_{2}$ \\
\hline CG320, Panasonic [13] & Pin-type; Primary & 192 & 20 & 203 & - \\
\hline MB306, PNNL [12] & Pin-type; Primary & 42 & 6 & 528 & $\mathrm{Li} / \mathrm{CF}_{\mathrm{X}}$ \\
\hline Microbattery by Sun et al. [34] & 3D; Secondary & 0.23 & 1 & 1260 & $\mathrm{LiFePO}_{4} / \mathrm{Li}_{4} \mathrm{Ti}_{5} \mathrm{O}_{12}$ \\
\hline Microbattery by Lai et al. [35] & Monolithic porous electrode; Secondary & 6 & 3 & 400 & $\mathrm{Li} / \mathrm{LiCoO}_{2}$ \\
\hline Microbattery by Pikul et al. [36] & 3D; Secondary & 0.03 & - & 150 & $\mathrm{MnO}_{2} / \mathrm{NiSn}$ \\
\hline
\end{tabular}

inorganic glassy or crystalline materials are typically used because of the dimensional stability and design flexibility. Batteries utilizing gel-polymer electrolytes are much thicker and therefore should be categorized as 'thick-film systems'. The inorganic electrolytes typically have much lower ionic conductivities than liquid electrolytes. This problem is partially mitigated by fabricating a very thin electrolyte layer (a few microns) to avoid large internal
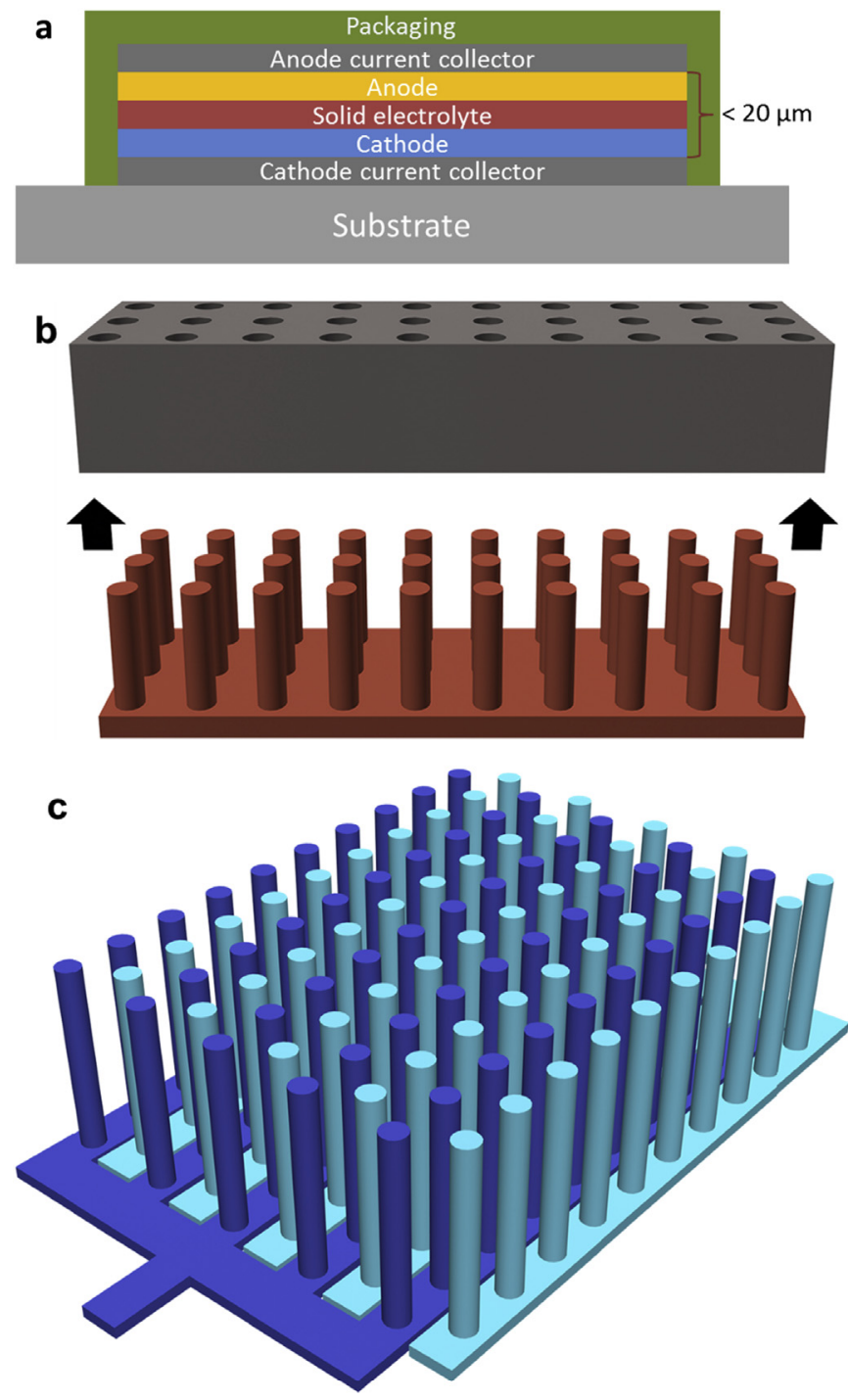

Fig. 2. Illustrated examples of microbattery architectures. (a) Thin-film battery; (b) 3D electrodes using template synthesis; (c) interdigitated electrodes. resistance. The overall thickness of the active layers (electrodes and electrolyte) generally does not exceed $20 \mu \mathrm{m}$, although the overall cell will be much thicker due to the need for robust packaging.

As the intrinsic transport properties of electrode materials limit the effective energy and power densities of thin-film batteries, cathode materials with both high electronic and ionic conductivities are highly desirable. $\mathrm{LiCoO}_{2}$ is the most commonly used cathode material for thin-film batteries (see more discussion in Section 2.2.). The most commonly used anode is Li metal, although Li-ion or Li-free anodes may be used to accommodate hightemperature processes required by solder reflow conditions [20]. For the electrolyte layer, several inorganic lithium ion conductors of a wide range of chemical compositions and crystal structures such as $\mathrm{Li}_{4} \mathrm{SiO}_{4}$ derivatives [21], NASICON [22], LISICON [23], perovskitetype LLTO [24], lithium phosphorus oxynitride (Lipon) [25,26], have been under investigation. Lipon developed by Oak Ridge National Laboratory delivered the best overall performance. Although Lipon has a fairly low ionic conductivity, it has a very high electronic resistivity so a pinhole-free barrier can be made as thin as several microns. More importantly, Lipon has excellent electrochemical stabilities ensuring its stable operation with metallic lithium, even at elevated temperatures. Deposition methods for the thin film fabrication include chemical vapor deposition, RF magnetron sputtering, pulsed layer deposition, sol-gel, etc.

Due to the stability of solid-state electrolyte and uniform current and charge distribution, thin-film batteries have much better rechargeability than liquid-electrolyte-based lithium ion batteries [27]. In addition, thin-film batteries are much more resistant to degradation at high temperatures and operation at temperatures as high as $150{ }^{\circ} \mathrm{C}$ has been demonstrated [28]. The all-solid-state design is also compatible with the fabrication processes of many devices thin-film batteries are integrated with, such as integrated circuits and solar panels. These favorable traits led to the successful commercialization of thin-film batteries with targeted application in radio-frequency identification (RFIDs), medical patches, smartcards, wireless sensors, etc. The major brands of thin-film batteries include Thinergy, EnerChip, Flexion. Thinergy batteries adopt the $\mathrm{LiCoO}_{2} /$ Lipon design whereas EnerChip batteries are built on silicon substrate designed to be directly placed on integrated circuits. Flexion batteries use polymer electrolyte and hence are flexible.

Despite the many advantages and commercial success of thinfilm batteries, they have a fatal shortcoming preventing them from meeting the increasing energy and power needs of the fastgrowing electronic sectors, especially the demand of MEMS. It is important to recognize that for small electronics and MEMS devices, the usable area is limited so traditional measures of batteries, namely volumetric energy and power densities are less relevant. Instead, the real issue is how much energy and power a device can deliver per areal footprint, measured in terms of $\mathrm{mAh} \mathrm{cm}^{-2}, \mathrm{~J} \mathrm{~cm}^{-2}$, $\mu \mathrm{W} \mathrm{m^{-2 }}$, etc. Long et al. have estimated that a smart dust has an energy demand of $1 \mathrm{~J} \mathrm{~mm}^{-2}$ [17]. Thin-film batteries have very 
limited areal energy density $\left(10^{-2} \mathrm{~J} \mathrm{~mm}^{-2}\right)$ because the electrode thicknesses cannot be increased without compromising the power density. Limited active surface area, high internal resistance due to solid-solid interfaces and low conductivities of electrolytes determine that thin-film microbatteries are at best a medium-power system. For the same reason, commercial thin-film batteries usually have fairly large area in order to possess meaningful capacities. The smallest commercial thin-film battery (to the best of our knowledge), EnerChip CNC005-BDC, have an area of $1.75 \mathrm{~mm} \times 2.15 \mathrm{~mm}$ and only $5 \mu \mathrm{Ah}$ capacity. The size and energy densities of several commercial lithium batteries [13,29-33] and reported cells [12,34-36] (in literature) are compared in Table 1. It can be seen that the energy density of commercial lithium batteries decrease with reducing sizes and there exists no commercial microbatteries that could combine small sizes and high energy densities. Further enhancement of microbattery performance requires the use of out-of-plane dimension through 3D design of battery components. Furthermore, there has been a strong demand for flexible batteries to power wearable and flexible gadgets. Major electronic devices manufacturers including Apple, LG and Nokia, already have plans to produce flexible batteries. Increasing demand by microelectronics for capacity, design flexibility and functionality drives the development of microbatteries towards 3D architecture and mechanical flexibility.

\subsection{D microbatteries and flexible microbatteries}

Many different 3D battery concepts have been proposed in order to enhance the areal energy and power densities. Several examples of reported high-performance 3D microbatteries are listed in Table 1 . They have comparable energy densities to conventional bulk-size batteries. The application of 3D geometry enlarges the electrode surface area per areal footprint therefore increasing the allowed current and amount of materials deposited. Locally, 3D batteries have similar geometry as thin-film batteries, i.e., thin layers of cathode, electrolyte, anode and current collectors. This is because the current density is material-limited and a short diffusion length needs to be maintained. The task of 3D design is to fold the basic layered 3D structure onto a 2D footprint while maintaining the short ionic and electronic current paths.

One approach of enlarging the electrode surface is nanostructuring or micro-fabricating 3D current collectors (may also act as substrates) with high aspect ratios followed by deposition of battery layers. Template synthesis is the most common method for forming 3D structures [37-40]. For example, by filling the pores of a porous membrane mask with current collector materials on a substrate and subsequently removing the membrane, arrays of micro-rods or micro-columns can be formed (Fig. 2b) and the diameter of the columns and the distance between the columns can be controlled by tuning the pore structures of the membranes. The pore-filling may be realized by sol-gel methods or electrochemical deposition. Instead of depositing current collectors, arrays of microrods of electrode materials can be deposited, but the electronic transport along the length of the rods becomes problematic. In an alternative method, instead of forming the 3D structure on (above) the substrates, micro-channels may be formed inside substrates by selective etching [41]. Both methods effectively enlarge surface area of the current collectors and hence active surface area of electrodes after the electrode materials are deposited. Besides porous membranes, polystyrene particles have been used to self-assemble into a 3D template [36,42]. Pores are infiltrated to form a 3D current collector scaffold. Obviously, using template synthesis, 3D structures of only one electrode can be fabricated. To construct a full cell, further deposition of the electrolyte, the opposite electrode and current collector is needed, or the half-cell is used against a planar
2D electrode in a liquid-electrolyte-filled cell.

The aforementioned methods effectively reduce transport lengths within the individual electrodes. In order to shorten transport paths of Li ions between two electrodes, interdigitated electrode designs have been proposed [43-45]. In this configuration, arrays of opposite electrodes are in close proximity to one another throughout the whole out-of-plane dimension (Fig. 2c). Fabrication of interdigitated electrodes requires patterning the photoresist using photolithography. It is also possible to adopt 3D printing techniques to form the pattern $[34,46]$. Microbatteries with this configuration consistently show much higher areal capacity than batteries with 2D electrodes. However, one problem is that the electrodes are generally mechanically fragile and breaking may lead to internal shorting. Also, charge distribution may be nonuniform [17].

Other proposed 3D architectures include aperiodic sponge-like electrodes [47]. They are generally produced by sol-gel method under supercritical conditions. This kind of solid framework has extremely large open space. However, infiltration and uniform deposition of other battery components can be challenging. Whatever the architecture is, the design principle of 3D microbatteries is the same: to enlarge active surface area without increasing electron and ion transport lengths. It is noteworthy that when liquid electrolytes are used, issues in conventional bulk-size batteries are also present especially in secondary microbatteries. For instance, large surface area in 3D microbatteries results in increased consumption of electrode materials by SEI formation, which limits the power density and rechargeability. Chemistries in microbatteries are often similar to bulk-size batteries so approaches to minimize adverse effects of SEI in bulk-size batteries such as electrolytes screening and incorporation of additives can be borrowed.

Recently, there has been a surge of interest in making lithium ion batteries mechanically flexible to keep pace with the development of flexible electronic components (OLED, memories, sensors, etc.) and to meet the demand of roll-up displays, wearable electronics, medical transplant devices, etc. Conventional LIBs are rigid mostly due to the rigidity of the packaging materials as liquid electrolytes pose stringent sealing requirements. Traditional solidstate thin-film batteries are brittle mainly due to the use of ceramic or metal substrates. However, it should be noted that the battery layers can accommodate certain degree of mechanical stress when they are thin. The realization of flexibility in recent research efforts mainly relies on the improvement of two aspects: material-derived flexibility and device-design-derived flexibility. In the former category, the use of flexible free-standing electrodes [48,49], polymer electrolytes $[50,51]$, current collectors (graphene paper $[52,53]$, conducting polymer), substrates [54] and packaging materials (PDMS) improves the flexibility of the battery layers. In the latter category, extra flexibility of full devices is gained by smart design of battery component layouts $[55,56]$. To understand this concept, one only needs to consider the example of flexibility in a spring which can be made of fairly rigid materials like hard plastics or metals.

Although size reduction and flexibility of batteries are two completely different concepts, the design ideas are, in many cases, compatible and overlapping. For instance, adoption of solid-state polymer electrolytes and nanostructured materials are viable approaches in both designs. In addition, a greater degree of design flexibility and novel architectures hold the key to success in both cases.

While the focus is on battery architecture, successful design of microbatteries also requires a good understanding of the properties, issues and fabrication methods of electrode and electrolyte materials because the appropriate choice of materials will depend 
very much on the targeted applications (power and energy requirements, safety consideration, cost, etc.). Therefore, this article will focus on the material choices and design concepts of highperformance microbatteries, and touch base on recent development of thin-film battery and flexible battery design. Various aspects of 3D batteries have been thoroughly reviewed previously [17-19] so we will only present the most recent progress through specific examples in this review.

\section{Materials and electrochemical couple selection}

\subsection{Cathode materials for primary micobatteries}

\subsection{1. $\mathrm{MnO}_{2}$}

Manganese dioxide and its derivatives represent a complex and diverse family of compounds with various electrochemical characteristics which has been reviewed by Thackeray et al. [2,57] Various forms of $\mathrm{MnO}_{2}$ have been investigated for applications in both primary and secondary lithium batteries. Most prominent rechargeable systems include spinel $\mathrm{Li}_{\mathrm{x}} \mathrm{Mn}_{2} \mathrm{O}_{4}$ [58-60], layered $\mathrm{Li}_{2} \mathrm{MnO}_{3}[61]$ and $\alpha-\mathrm{MnO}_{2}$ [62-64]. For non-rechargeable systems, the heat-treated electrolytic manganese dioxide (HEMD) developed by Ikeda et al. [65] in 1975 is the most common and commercially successful cathode material, widely used in batteries of portable consumer products since the 1980s [66]. The Manganese dioxides are inexpensive and non-toxic with high specific energy densities (around $200 \mathrm{mAh} \mathrm{g}{ }^{-1}$ ). $\mathrm{Li} / \mathrm{MnO}_{2}$ batteries offer a high nominal voltage of $3 \mathrm{~V}$ with slow self-discharge and operate over a wide temperature range [67,68].

Among several polymorphs of $\mathrm{MnO}_{2}$, the $\gamma-\mathrm{MnO}_{2}$ is the most electrochemically active form which consists of domains of pyrolusite $\left(\beta-\mathrm{MnO}_{2}\right)$ and ramsdellite $[2,69]$. It can be prepared chemically [70] or electrolytically $[68,71]$. Ikeda et al. showed that dehydration of electrolytic manganese dioxide through heat treatment $\left(>300^{\circ} \mathrm{C}\right)$ improved the discharge characteristics [67,68]. The proposed discharge mechanism below for reduction of $\mathrm{Mn}^{4+}$ to $\mathrm{Mn}^{3+}$ through intercalation of $\mathrm{Li}^{+}$was confirmed by later reports with added details about the multistep discharging [72-76].

$\mathrm{xLi}+\mathrm{MnO}_{2} \rightarrow \mathrm{Li}_{\mathrm{X}} \mathrm{MnO}_{2}$

Lithium manganese batteries are used mostly in low or medium power applications. The poor high-rate discharge ability of the Li/ $\mathrm{MnO}_{2}$ battery hinders its application in areas where higher power outputs are needed [77]. It has been demonstrated that the use of nanostructured $\mathrm{MnO}_{2}$ can improve the high-rate discharge performance of $\mathrm{Li} / \mathrm{MnO}_{2}$ batteries [78,79]. Nanostructured $\mathrm{MnO}_{2}$ is of particular interest in electrochemical capacitors and a large volume of literature can be found on this subject [80-83]. Surface coatings have also been applied to improve the electrochemical properties of $\mathrm{MnO}_{2}[84,85]$.

As EMD can be readily deposited galvanostatically to form conformal films, they have been applied in various microbatteries with 3D architecture [36,86-88]. Typically, a substrate or scaffold is immersed in a $\mathrm{Mn}^{2+}$ solution and $\mathrm{MnO}_{2}$ is deposited Faradaically according to the reaction

$\mathrm{Mn}^{2+}+2 \mathrm{H}_{2} \mathrm{O} \rightarrow \mathrm{MnO}_{2}+4 \mathrm{H}^{+}+2 \mathrm{e}^{-}$

The thickness and conformality of the film can be controlled by the deposition conditions. Microbatteries with a vertical array of $\mathrm{MnO}_{2}$ nanowires as the cathode showed a high capacity and good rate capability [87]. The microbattery with three-dimensional bicontinuous interdigitated microelectrodes designed by Pikul et al. has exceptionally high power density of $7.4 \mathrm{~mW} \mathrm{~cm}^{-2} \mu \mathrm{m}^{-1}$ and decent energy density (about $1 \mu \mathrm{Wh} \mathrm{cm}^{-2} \mu \mathrm{m}^{-1}$ ) [36].

\subsection{2. $C F_{X}$}

The $\mathrm{Li} / \mathrm{CF}_{x}$ primary battery has the highest energy density $\left(\sim 2180 \mathrm{Wh} \mathrm{kg}^{-1}\right.$ when $\left.\mathrm{x}=1\right)$ compared to other primary lithium batteries such as $\mathrm{Li} / \mathrm{SOCl}_{2}$ and $\mathrm{Li} / \mathrm{MnO}_{2}$ batteries [66]. Other advantages include high operating voltage and slow self-discharge rate. Watanabe et al. first demonstrated the use of $\mathrm{CF}_{\mathrm{x}}$ in primary batteries [3]. $\mathrm{Li} / \mathrm{CF}_{\mathrm{X}}$ batteries were commercialized in the 1970 s. The overall discharge reaction of the $\mathrm{Li} / \mathrm{CF}_{\mathrm{X}}$ battery is as follows:

$\mathrm{xLi}+\mathrm{CF}_{\mathrm{X}} \rightarrow \mathrm{C}+\mathrm{xLiF}$

$\mathrm{Li} / \mathrm{CF}_{\mathrm{X}}$ batteries are used mainly in low power application such as implantable medical devices due to the slow kinetics at the $\mathrm{CF}_{\mathrm{x}}$ cathode [89-91]. Two main contributors to the slow kinetics are poor electronic conductivity of $\mathrm{CF}_{x}$ [92] and large activation energy associated with breaking the $\mathrm{C}-\mathrm{F}$ bonds, both as a result of the strong covalent nature of $\mathrm{C}-\mathrm{F}$ bonds. In addition, the reaction product LiF further blocks the electronic conduction [91,93], deteriorating the discharge performance. Consequently, $\mathrm{Li} / \mathrm{CF}_{\mathrm{x}}$ batteries suffer from low power density, decreased practical energy density, initial voltage delay, poor low temperature performance and heat generation [66].

$\mathrm{CF}_{\mathrm{X}}$ is typically synthesized through fluorination of various carbon materials, most commonly graphite, 1 ) at high temperatures in the present of $F_{2}$ gas [94-96] or 2) at ambient temperature catalyzed by hydrogen fluoride or metal fluoride [97-100]. Both methods are capable of tuning the $\mathrm{C} / \mathrm{F}$ ratio by changing the reaction temperature, the fluorine gas partial pressure or catalysts. Over-fluorination $(\mathrm{x}>1)$ leads to the formation of inactive $\mathrm{CF}_{2}$ group [101,102]. While the CF (carbon monofluoride) is insulating, it is known that the $\mathrm{C}-\mathrm{F}$ bond becomes more ionic as $\mathrm{x}$ decreases, leading to faster reaction kinetics [89,103-105]. This is accompanied by a decrease of discharge capacity as fluorine is the active element. Therefore, a tradeoff exists between rate capability and energy density. The energy and power densities of the $\mathrm{Li} / \mathrm{CF}_{x}$ battery are tunable by adjusting the $\mathrm{C} / \mathrm{F}$ ratio.

Currently, the research on the $\mathrm{Li} / \mathrm{CF}_{x}$ system mainly focuses on two directions:

\section{(1) Optimizing/developing the fluorination process.}

Thermal treatment of high-temperature $\mathrm{CF}_{\mathrm{X}}$ increases the quantity of sub-fluorinated carbon and improves rate capability $[91,106]$. The $\mathrm{C}-\mathrm{F}$ bonds of $\mathrm{CF}_{\mathrm{X}}$ materials prepared by the roomtemperature catalytic approach have more ionic character than compounds using the high-temperature approach, leading to cells with higher voltage and better kinetics $[97,99,103]$. The less invasive low-temperature process also helps preserve the pore structures of various carbon materials [107]. However, residual catalysts may be present causing aging issues and need to be removed by thermal treatment $[103,108]$.

\section{(2) Studying on different carbon materials for fluorination.}

Besides graphite, many different types of novel carbon materials had been employed for fluorination such as carbon nanotubes [109], carbon nanofibers [110], fullerene [111-113], mesoporous carbon [107], graphene [114], etc. These carbon materials generally possess high surface area and good intrinsic electrical conductivity which have been proven to be beneficial to the electrochemical performance of $\mathrm{Li} / \mathrm{CF}_{\mathrm{X}}$ cells. In particular, a series of fluorinated graphene with different fluorination levels $\left(\mathrm{CF}_{x}, x=0.47,0.66,0.89\right)$ have been synthesized via controlling fluorination temperature and time [114]. Low rate $(C / 10)$ performance of different fluorinated graphene materials (Fig. 3a) indicated that the operational voltage 

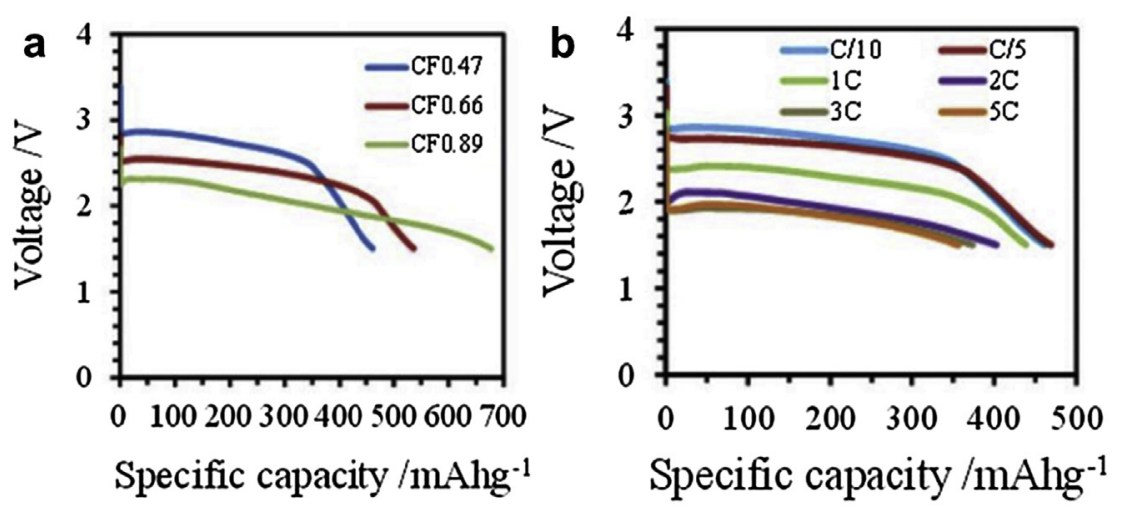

Fig. 3. (a) Low rate $(\mathrm{C} / 10)$ performance of fluorinated graphene with different $\mathrm{C} / \mathrm{F}$ ratio. (b) Rate performance of $\mathrm{CF}_{0.47}$. Reprinted with permission from Ref. [114].

increases with lower fluorine content in $\mathrm{CF}_{x}$ while the capacity decreases slightly. This correlation with fluorination level is consistent with fluorinated graphite although the performance is far superior [115]. $\mathrm{CF}_{0.47}$ exhibited a promising capacity of $356 \mathrm{mAh} \mathrm{g}^{-1}$ at a high rate of $5 \mathrm{C}$ (Fig. 3b). The higher discharge voltage $(\sim 2.8 \mathrm{~V})$ and superior rate performance in $\mathrm{CF}_{0.47}$ indicates faster solvated $\mathrm{Li}^{+}$diffusion due to the high surface area graphene with expanded inter-layer spaces. Other systems that exhibit high capacity at high current densities include soft-templated mesoporous carbon (MC) [107] and carbon nanofibers [110]. Fulvio et al. showed that fluorinated activated $\mathrm{MC} \mathrm{CF}_{0.55}$ has a discharge capacity of more than $400 \mathrm{mAh} \mathrm{g}^{-1}$ at $5 \mathrm{C}$ rate while maintaining high discharge voltage $(2.8 \mathrm{~V})$. The superior performance was attributed to the hierarchical pore structure of micro- and mesopores. Fluorinated carbon nanofibres $\mathrm{CF}_{0.76}$ have maximum power density of $8057 \mathrm{~W} \mathrm{~kg}^{-1}$. These studies opened up possibilities for the application of carbon fluoride materials in high-power energy storage devices.

\subsubsection{Silver vanadium oxide}

Silver vanadium oxides encompass a variety of phases containing $\mathrm{Ag}, \mathrm{V}$ and $\mathrm{O}$ with different stoichiometries $\left(\mathrm{AgVO}_{3}, \mathrm{Ag}_{\mathrm{x}} \mathrm{V}_{2} \mathrm{O}_{5}\right.$, $\mathrm{Ag}_{\mathrm{x}} \mathrm{V}_{4} \mathrm{O}_{11}$ [116-118], etc.) and electrochemical characteristics, thanks to the rich chemistry of the $\mathrm{Ag}_{2} \mathrm{O}-\mathrm{V}_{2} \mathrm{O}_{5}$ system [119]. The multiple oxidation states of $\mathrm{Ag}$ and $\mathrm{V}$ also ensure good electron transfer properties of these compounds. $\mathrm{Ag}_{2} \mathrm{~V}_{4} \mathrm{O}_{11}$ is the most studied and commercially successful compound, widely used in implantable cardiac defibrillators (ICDs) $[10,120,121]$. The choice of $\mathrm{Ag}_{2} \mathrm{~V}_{4} \mathrm{O}_{11}$ has been discussed by Takeuchi et al. [4] An ICD requires its power source to supply a low current over a long period of time and a strong current pulse when needed. $\mathrm{Ag}_{2} \mathrm{~V}_{4} \mathrm{O}_{11}$, possessing a relatively high theoretical capacity of $315 \mathrm{mAh} \mathrm{g}^{-1}$ [122], high-rate capability [4] and low self-discharge rate [123], is the ideal cathode material for this need. In addition, the multi-step discharge profile of $\mathrm{Ag}_{2} \mathrm{~V}_{4} \mathrm{O}_{11}$ enables measurement of depth of discharge (DOD) and indication of end of life. The conventional preparation methods of $\mathrm{Ag}_{2} \mathrm{~V}_{4} \mathrm{O}_{11}$ are 1) thermal decomposition of $\mathrm{AgNO}_{3}$ and $\mathrm{V}_{2} \mathrm{O}_{5}$ [120]; 2) addition reaction of $\mathrm{Ag}_{2} \mathrm{O}$ or $\mathrm{AgVO}_{3}$ with $\mathrm{V}_{2} \mathrm{O}_{5}$ [124]. The surface morphology and hence the electrochemical properties were found to be dependent on the synthesis temperatures [125]. $\mathrm{Ag}_{2} \mathrm{~V}_{4} \mathrm{O}_{11}$ has a layered structure consisting of $\mathrm{V}_{4} \mathrm{O}_{11}$ slabs with silver ion between the layers [126,127]. The discharge characteristic of the $\mathrm{Ag}_{2} \mathrm{~V}_{4} \mathrm{O}_{11}$ cathode has been extensively studied. A maximum of 7 lithium ions can be intercalated through multiphase reactions:

$7 \mathrm{Li}+\mathrm{Ag}_{2} \mathrm{~V}_{4} \mathrm{O}_{11} \rightarrow \mathrm{Li}_{7} \mathrm{~V}_{4} \mathrm{O}_{11}+2 \mathrm{Ag}$

The voltage profile of silver vanadium oxide (SVO) exhibits a multi-plateau curve from $3.3 \mathrm{~V}$ down to $2.0 \mathrm{~V} \mathrm{~V}^{5+}$ and $\mathrm{Ag}^{+}$are first reduced simultaneously to $\mathrm{V}^{4+}$ and $\mathrm{Ag}$ metal which is followed by a partial reduction of $\mathrm{V}^{4+}$ to $\mathrm{V}^{3+}[122,128-130]$. The formation of $\mathrm{Ag}$ phase further enhances the electronic conductivity by 5 orders of magnitude [131]. The diffusion coefficient of Li has been determined to be on the order of $10^{-10}$ to $10^{-9} \mathrm{~cm}^{2} \mathrm{~s}^{-1}$ depending on the DOD which is the limiting factor at high rate [129]. Attempts of utilizing SVO as rechargeable cathode materials face challenges of capacity retention as Ag is difficult to be reinserted [132,133].

Recent research on SVO focuses on improvement of material properties through novel synthesis routes. Specifically, roomtemperature precipitation method [134], electrospinning and hydrothermal method [135], microwave synthesis [136] molten salt synthesis [137], sol-gel assisted by ultrasonic radiation [138], and rheological phase method [139] have been attempted. Some methods resulted in materials with nanostructures possessing higher specific capacity at a faster rate than conventional solid state synthesis. Furthermore, the rechargeability was improved greatly indicating enhancement of reversibility of $\mathrm{Ag}$ reduction. For instance, $\beta-\mathrm{Ag}_{0.33} \mathrm{~V}_{2} \mathrm{O}_{5}$ prepared by electrospinning technique followed by a hydrothermal process showed high capacity retention of $180 \mathrm{mAh} \mathrm{g}^{-1}$ after 30 cycles [135]. A hybrid system has become popular for high-rate applications where a dual cathode (separate sheet of $\mathrm{CF}_{\mathrm{X}}$ and $\mathrm{Ag}_{2} \mathrm{~V}_{4} \mathrm{O}_{11}$ ) was used [140]. This system has $21 \%$ more capacity than pure SVO cells while maintaining the power capability. Fig. 4 shows that the hybrid system has discharge voltage characteristics of both SVO and CF cathodes so it also provides much better end-of-service indication due to its flat plateau of voltage as the cathode is depleted $[140,141]$. Note that a key to this design is the rechargeability of the SVO cathode which allows the recharge of the SVO cathode by the $\mathrm{CF}_{\mathrm{X}}$ cathode after a strong current pulse.

\subsection{Cathode materials for secondary microbatteries}

\subsection{1. $\mathrm{LiCoO}_{2}$}

Lithium Cobalt Oxide has been demonstrated as a mature, industry-standard battery material that provides long cycle life and very high energy density $[15,142]$. $\mathrm{LiCoO}_{2}$ adopts two different structures depending on the synthesis condition [143]. The cubic spinel-type $\mathrm{LiCoO}_{2}$ [144], also known as the low temperature $\mathrm{LiCoO}_{2}\left(\mathrm{LT}-\mathrm{LiCoO}_{2}\right)$, has relatively poor cyclability and low operating voltage [145] as compared to the hexagonal layered structure $\mathrm{LiCoO}_{2}\left(\mathrm{HT}-\mathrm{LiCoO}_{2}\right)$ [146], which operates at around $3.9 \mathrm{~V}$ against pure Li metal [147]. Therefore, the $\mathrm{HT}-\mathrm{LiCoO}_{2}$ has been the preferable choice. It is generally accepted that $\mathrm{LiCoO}_{2}$ should not be charged over $4.2 \mathrm{~V}$ (extracting more than $0.5 \mathrm{~mol}$ of $\mathrm{Li}$ ) in order to 

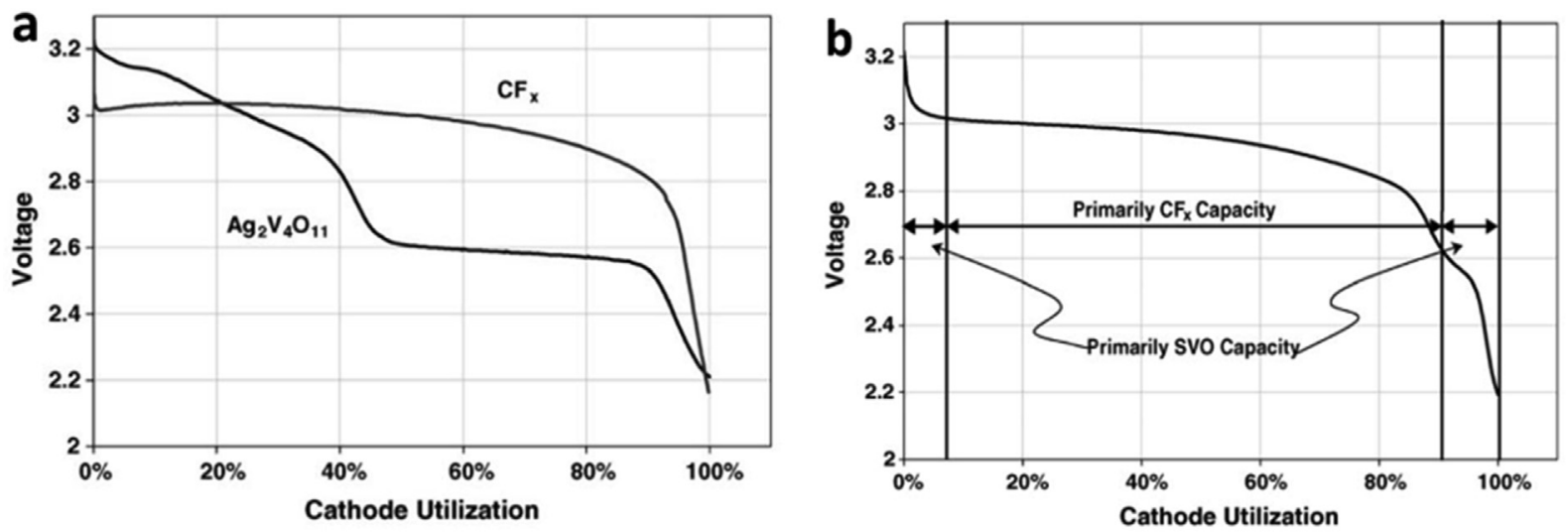

Fig. 4. (a) Discharge voltage of $\mathrm{Ag}_{2} \mathrm{~V}_{4} \mathrm{O}_{11}$ and $\mathrm{CF}$ cathodes; (b) discharge voltage of a $\mathrm{Ag}_{2} \mathrm{~V}_{4} \mathrm{O}_{11}-\mathrm{CF}$ hybrid cathode system. Reprinted with permission from ref [141].

maintain good reversibility as the hexagonal-to-monoclinic phase transition at $\mathrm{x}=0.5$ (as in $\mathrm{Li}_{\mathrm{x}} \mathrm{CoO}_{2}$ ) is not as reversible, giving rise to a theoretical capacity of $137 \mathrm{mAh} \mathrm{g}^{-1}[148,149]$. Various modifications including surface coating $[150,151]$ and alternative electrolytes [152] have been proven effective in reducing the capacity fading when charged to $4.5 \mathrm{~V}$. However, a highly-reversible capacity of over $180 \mathrm{mAh} \mathrm{g}^{-1}$ is unlikely. The voltage profile features a plateau at around $3.9 \mathrm{~V}$ vs. the $\mathrm{Li} / \mathrm{Li}^{+}$reference electrode indicating two-phase coexistence for $0.75<\mathrm{x}<0.93$ [149]. $\mathrm{LiCoO}_{2}$ also possesses good rate capability due to its excellent electronic and ionic conductivities. Although $\mathrm{LiCoO}_{2}$ behaves as an insulator, the electronic conductivity of $\mathrm{Li}_{\mathrm{x}} \mathrm{CoO} 2$ increases quickly as $\mathrm{Li}$ is extracted, marking a metal-insulator transition [153,154]. The Li diffusion coefficient of $\mathrm{Li}_{\mathrm{x}} \mathrm{CoO}_{2}$ ranges from $10^{-11}$ to $10^{-12} \mathrm{~m}^{2} \mathrm{~s}^{-1}$ [155]. Both the electronic conductivity and ion diffusion are highly anisotropic so strong orientation effects have been observed for $\mathrm{LiCoO}_{2}$ thin films $[143,156,157]$.

$\mathrm{LiCoO}_{2}$ remains a popular choice of cathode material for microbatteries due to the good understanding of its properties and relative ease of preparation. A number of preparation techniques have been applied to successfully prepare $\mathrm{LiCoO}_{2}$ electrodes. Most notably, Bates et al. [158] at Oak Ridge National Laboratory developed all-solid-state thin-film batteries with radio frequency (RF) magnetron sputtered $\mathrm{LiCoO}_{2}$ thin films as the cathode and Lipon as the electrolyte, which displayed a high utilization rate at high current density and extremely stable capacity. Only $0.001 \%-0.002 \%$ of the capacity was lost per cycle. The capacity faded quickly with increasing thickness of the thin film so the thickness was limited to $1 \mu \mathrm{m}$. $\mathrm{LiCoO}_{2}$ thin films produced with pulsed laser deposition (PLD) have been studied by Striebel et al. [159] A near full utilization was achieved on the first cycle for the $0.2 \mu \mathrm{m}$ thick film but high rate of capacity fading was observed which was attributed to the degradation of liquid electrolyte used. Recently, to investigate the applicability of garnet-type lithium ion conductors, an all-solidstate battery with $\mathrm{LiCoO}_{2}$ thin-film electrode by PLD was constructed and shown to possess high initial capacity and good capacity retention [160]. Techniques such as chemical vapor deposition [161] and electroplating [162] can produce conformal films and are of potential use in 3D structured cathodes. Hydrothermal [163] and sol-gel [164] methods have also been attempted to prepare $\mathrm{LiCoO}_{2}$ thin films. The aforementioned techniques are useful for producing thin films less than $10 \mu \mathrm{m}$. Kim et al. [165] demonstrated the usefulness of the laser printing technique in the preparation of porous $\mathrm{LiCoO}_{2}$ thick films (up to $100 \mu \mathrm{m}$, see Fig. 5a), which has a significantly higher discharge capacity $\left(2360 \mu \mathrm{Ah} \mathrm{cm}^{-2}\right)$. In addition, laser structuring of deposited films improves the capacity retention (Fig. 5b). Although the thin-film electrode is the standard geometry for microbatteries, Lai et al. [35] demonstrated that the monolithic $\mathrm{LiCoO}_{2}$ pellet with $25 \%$ open porosity (Fig. 6a) obtained by solid-state sintering can achieve full utilization at $\mathrm{C} / 10$ rate and $80 \%$ of capacity at $\mathrm{C} / 3$ rate (Fig. $6 \mathrm{~b}$ ). Compared to conventional composite electrodes, the denselysintered electrodes provided 4-10 times higher areal loading and energy densities normally achieved in batteries that are more than 100 times larger in volume. No apparent mechanical damage was observed upon cycling which was explained by the proposed damage-accommodation mechanism. Microbatteries using the thick $\mathrm{LiCoO}_{2}$ can deliver energy densities of up to $675 \mathrm{Wh} \mathrm{L}^{-1}$ at a C/ 3 rate. The ultrahigh energy density can be attributed to efficient packing and the use of a single-layer electrode thus avoiding multiple layers of inactive components.

\subsubsection{Spinel $\mathrm{LiMn}_{2} \mathrm{O}_{4}$ system}

As an alternative to $\mathrm{LiCoO}_{2}$, the spinel $\mathrm{LiMn}_{2} \mathrm{O}_{4}$ system exhibits comparable specific capacity, high voltage and decent cycle life. In addition, the use of abundant element Mn with low toxicity presents a great advantage from the standpoint of volume production. The compound $\mathrm{LiMn}_{2} \mathrm{O}_{4}$ possesses a cubic spinel structure with $\mathrm{Li}$ occupying the tetrahedral, 8a sites, and Mn occupying the octahedral, $16 \mathrm{~d}$ sites. The interstitial sites for $\mathrm{Li}, 16 \mathrm{c}$, share faces with the occupied sites, forming a continuous three-dimensional diffusion network defined by the $\mathrm{Mn}_{2} \mathrm{O}_{4}$ framework. Thackery et al. [166,167] have shown that $\mathrm{Li}$ can be reversibly inserted or extracted for the compositional range of $0<\mathrm{x}<2.2$ in $\mathrm{Li}_{\mathrm{x}} \mathrm{Mn}_{2} \mathrm{O}_{4}$. Electrochemical and diffraction studies revealed three steps of the electrochemical reaction: 1) a coexistence of two cubic spinel phases with a constant open circuit voltage (OCV) of $4.1 \mathrm{~V} \mathrm{vs}$. $\mathrm{Li} / \mathrm{Li}^{+}$for $\mathrm{x}<0.6 ; 2$ ) a single phase reduction of cubic spinel with a sloping profile of OCV around $3.9 \mathrm{~V}$ for $0.6<\mathrm{x}<1 ; 3$ ) a coexistence of cubic and tetragonal phases with OCV at $2.95 \mathrm{~V}$ for $1<\mathrm{x}<2$ [58]. The cubic-tetragonal phase transition is driven by the Jahn-Teller distortion of $\mathrm{MnO}_{6}$ octahedron as $\mathrm{Mn}^{4+}$ is reduced to $\mathrm{Mn}^{3+}$, resulting in a $6.5 \%$ increase of the unit cell volume. Nevertheless, the spinel skeleton is not destroyed by the phase transition. The large separation of OCV between step 2 and step 3 may also be explained in terms of JahnTeller distortion. Cycling test showed that the capacity loss is greater when cycled over the entire voltage range of $2.0 \mathrm{~V}-4.5 \mathrm{~V}$ rather than utilizing only the high voltage regions (3.5 V-4.5 V), which was attributed to the poor structural integrity during cubictetragonal phase transition [168]. Thereafter, spinel $\mathrm{LiMn}_{2} \mathrm{O}_{4}$ is primarily regarded as a $4 \mathrm{~V}$ system with theoretical capacity of $154 \mathrm{mAh} \mathrm{g}^{-1}$. 

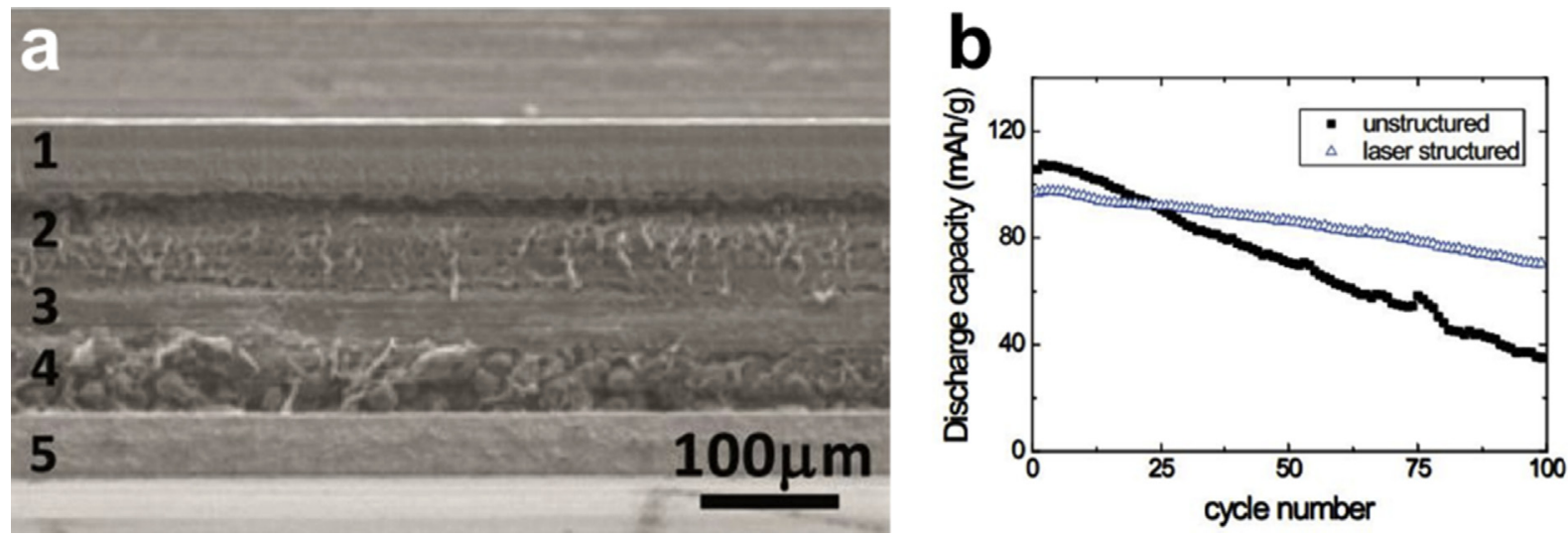

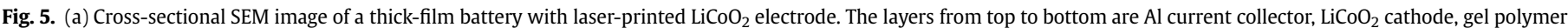
electrolyte, carbon anode and $\mathrm{Cu}$ current collector. (b) Cycling performance of laser-printed $\mathrm{LiCoO}_{2}$ cathode films. Reprinted with permission from Ref. [165].
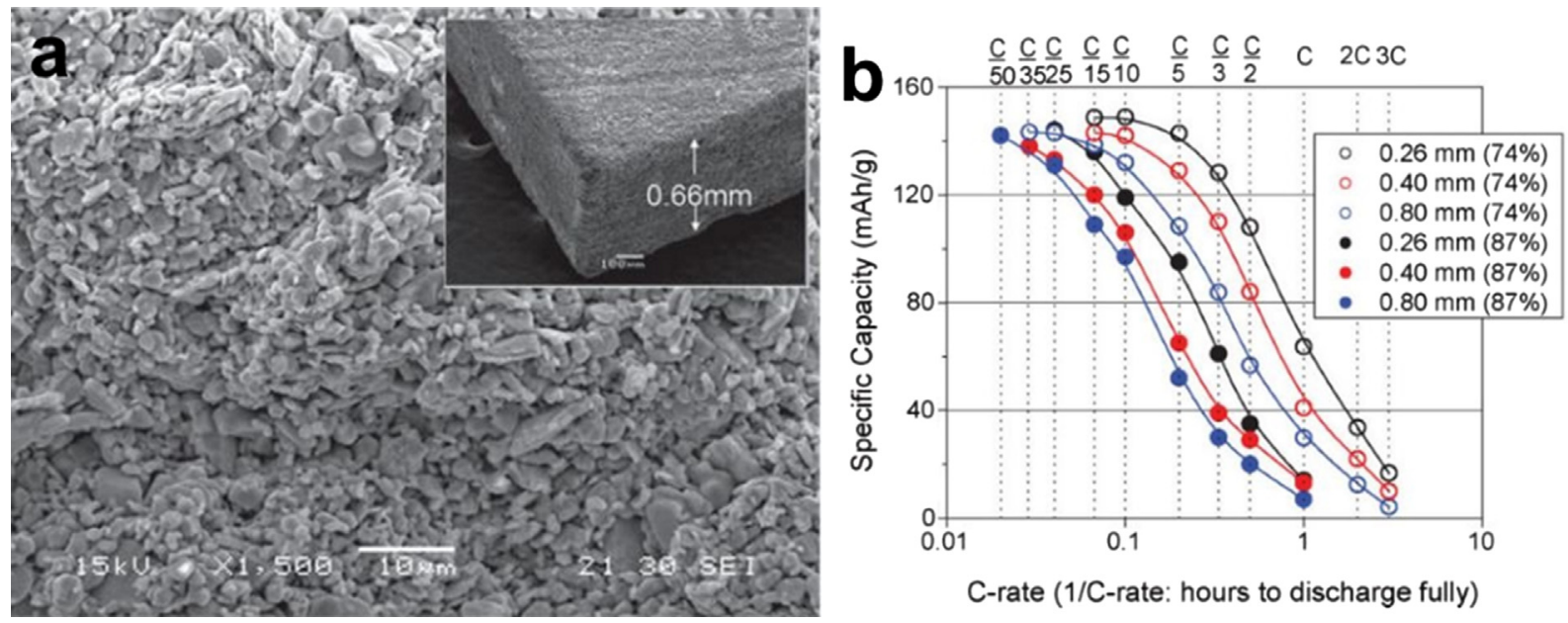

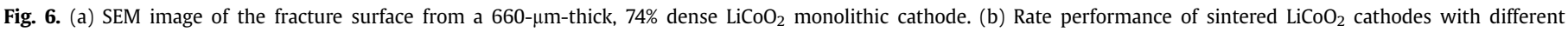
thicknesses and densities. Reprinted with permission from Ref. [35].

Two main factors contribute to the capacity loss of $\mathrm{LiMn}_{2} \mathrm{O}_{4}$ during cycling. The first is the onset of the Jahn-Teller distortion when $\mathrm{x}$ approaches 1 in $\mathrm{Li}_{\mathrm{x}} \mathrm{Mn}_{2} \mathrm{O}_{4}$. To circumvent this problem, compounds of partial replacement of $\mathrm{Mn}$ with $\mathrm{Li}$ or multivalent cations $\left(\mathrm{Li}_{1+\mathrm{x}} \mathrm{Mn}_{2-\mathrm{x}} \mathrm{O}_{4}, \mathrm{LiMg}_{\mathrm{x} / 2} \mathrm{Mn}_{2-\mathrm{x}} \mathrm{O}_{4}\right)$ were proposed [59]. The substitution increased the average valence of Mn therefore suppressing the onset of Jahn-Teller effect. The rechargeability was indeed improved with substitution. However, this approach inevitably reduces the theoretical capacity so only a small quantity of substitution is desirable. It is found that the synthesis conditions strongly affect the electrochemical performance of $\mathrm{LiMn}_{2} \mathrm{O}_{4}$ as cation mixing and nonstoichiometry are common for the spinel family and can be strongly dependent on the thermal history $[169,170]$. Tarascon et al. showed that the capacity fading problem can be partially overcome by optimizing the synthesis conditions. Another problem with the spinel $\mathrm{LiMn}_{2} \mathrm{O}_{4}$ system is the $\mathrm{Mn}$ dissolution. Specifically, the $\mathrm{Mn}^{3+}$ undergoes a dismutation reaction catalyzed by acidic species to form $\mathrm{Mn}^{4+}$ and soluble $\mathrm{Mn}^{2+}$. $\mathrm{Mn}^{2+}$ then reacts with the liquid electrolyte $\left(\mathrm{PF}_{6}\right.$ salt) to generate more acidic products [171]. This issue becomes non-existent with the use of solid-state electrolytes in thin-film batteries.

Recent research focus has been directed to the use of nanostructured electrodes to improve the electrode utilization and capacity retention. Bruce's group [172] developed ordered mesoporous $\mathrm{Li}-\mathrm{Mn}-\mathrm{O}$ spinel by a hard templating route. The thin walls of mesopores ( $7 \mathrm{~nm}$ ) ensure fast kinetics and accommodate mechanical strain whereas micron-size particles ensure efficient packing and good contact. Overall, the mesoporous $\mathrm{Li}_{1.12} \mathrm{Mn}_{1.88} \mathrm{O}_{4}$ exhibits superior gravimetric and volumetric energy density than bulk material, especially at a high rate. It also displays, counterintuitively, greater capacity retention at $50{ }^{\circ} \mathrm{C}$ (Fig. 7a) despite having a much larger surface area. Mn dissolution tests revealed that the mesoporous spinel had the least Mn dissolution. Alternatively to the mesoporous spinel, Tang et al. [173] developed aqueous rechargeable batteries using $\mathrm{LiMn}_{2} \mathrm{O}_{4}$ nanotubes as the cathode material. An impressive charging rate of $600 \mathrm{C}$ was achieved with $53.9 \%$ of capacity retention (Fig. 7b). Factors contributing to excellent rate capability include the nanostructured cathode, preferred crystal orientation, high ionic conductivity of the aqueous electrolyte and absence of SEI. In addition, no capacity loss was observed after 1200 cycles which can be attributed to the reduced Mn dissolution in aqueous medium.

Most $\mathrm{LiMn}_{2} \mathrm{O}_{4}$ microbatteries adopt the thin-film geometry. Thin films with various thicknesses and porosity have been prepared using electrostatic spray deposition (ESD) [174], pulsed laser deposition (PLD) [159,175], sol-gel method [176], reactive electron beam evaporation [177,178], RF magnetron sputtering [179-182], etc. Similar to the $\mathrm{LiCoO}_{2}$ thin films, the most successful technique 

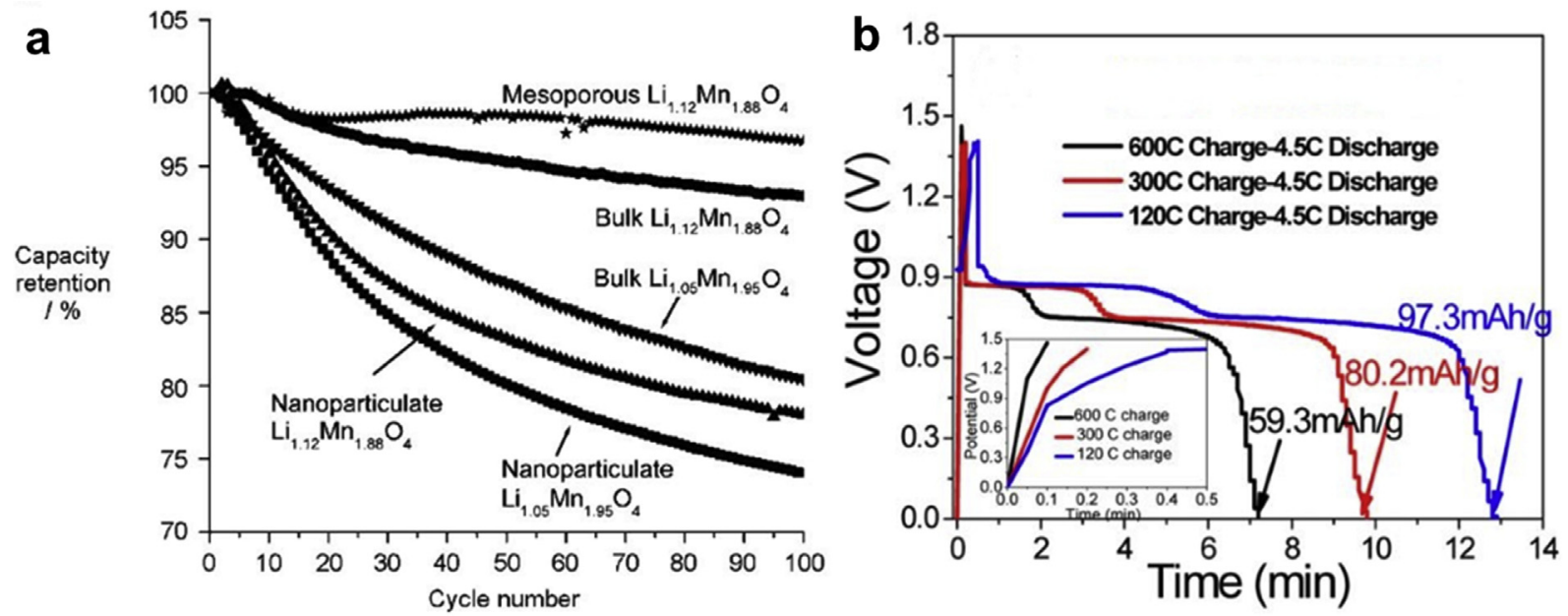

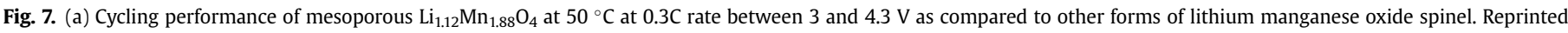

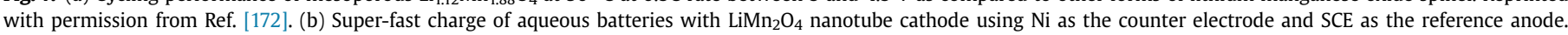
Reprinted with permission from Ref. [173].

is the RF magnetron sputtering. Using this technique, Hwang et al. [181] prepared $\mathrm{LiMn}_{2} \mathrm{O}_{4}$ thin films of $2000 \AA$ 践 thess, which were tested in a $\mathrm{LiMn}_{2} \mathrm{O}_{4} / 1 \mathrm{M} \mathrm{LiClO}_{4}$ in PC $+\mathrm{DME} / \mathrm{Li}$ cell. As the formation of crystalline spinel phase is crucial to rechargeability, the high-temperature annealing process is generally needed. The film annealed at $750{ }^{\circ} \mathrm{C}$ showed the best rechargeability, i.e., only $2 \%$ of capacity loss after more than 1000 cycles at a current density of $200 \mu \mathrm{A} \mathrm{cm}^{-2}$. Bates et al. did an extensive study of $\mathrm{LiMn}_{2} \mathrm{O}_{4} / \mathrm{Lipon}$ cells and showed that the cell can be cycled for many thousands of cycles [27]. Recently, crystalline $\mathrm{LiMn}_{2} \mathrm{O}_{4}$ films were deposited at low temperatures $\left(<300{ }^{\circ} \mathrm{C}\right)$ on ITO/Pt/Al substrate, which may enable the fabrication of flexible $\mathrm{LiMn}_{2} \mathrm{O}_{4}$ microbatteries using polymer substrates [179].

\subsection{Anode materials}

Although no longer used in commercial bulk-size lithium ion batteries for safety reasons, Li metal is the most used anode material for lithium microbatteries, especially the primary systems. The Li anode has advantages of high energy and light weight, easy fabrication, etc. It can be deposited by thermal deposition [26] or simply attached. Since solid-state electrolytes are widely adopted in rechargeable thin-film microbatteries, the safety issues related to the use of Li metal become less of a concern. For 3D microbatteries, as the focus is mostly on the cathode side and the research is still in the proof-of-concept stage, Li metal provides an easy, reliable anode for cell testing.

For secondary microbatteries, other anode materials that are commonly used include group IVA elements (C, Si, Sn, etc.). Li-Si alloy has extremely high theoretical capacity of $4000 \mathrm{mAh} \mathrm{g}^{-1}$ [183], comparable to metallic Li. Si is also the pillar material of the electronic industry with mature processing technology so the use of silicon in batteries facilitates integration with other electronic devices. The greatest challenge to use $\mathrm{Si}$ as the anode is the extreme volume expansion by Li intercalation [184]. Fortunately, it has been proven that very thin layers of $\mathrm{Si}$ can accommodate mechanical strain during Li intercalation/extraction [185] so capacity fades can be partially circumvented by designing a nanostructured $\mathrm{Si}$ anode with large empty space for volume expansion or fabricating Si thin films [186-189].

$\mathrm{Li}_{4} \mathrm{Ti}_{5} \mathrm{O}_{12}$ (LTO) is another important anode material due to its small volume expansion during cycling and hence excellent cycle life [190,191]. Another factor that contributes to its stable cycling is the absence of SEI layers as the electrochemical process occurs at $1.5 \mathrm{~V}$ vs. $\mathrm{Li} / \mathrm{Li}^{+}$. Nevertheless, the reversible capacity of LTO is only about $160 \mathrm{mAh} \mathrm{g}^{-1}$. $\mathrm{Li}_{4} \mathrm{Ti}_{5} \mathrm{O}_{12}$ has been successfully deposited by sol-gel methods [192-194], pulsed laser deposition [195], sputtering techniques [196], etc. It remains an excellent choice of anode materials when the primary concern is cycle life and stability instead of power and energy densities.

An important consideration in the design of microbatteries is the appropriate use of deposition method. The ability to conformally deposit anode materials will provide an extra degree of design flexibility. From this perspective, anode materials such as $\mathrm{Ni}-\mathrm{Sn}$ alloy or $\mathrm{TiO}_{2}$ are favored for 3D microbatteries as they can be deposited onto topologically complex objects by electrodeposition or atomic layer deposition. The pure $\mathrm{Sn}$ anode has high initial capacity but suffers from large volume expansion, similar to the $\mathrm{Si}$ anode. Alloying with $\mathrm{Ni}$ buffers the volume variation thus improving cyclability. However, $\mathrm{Ni}$ is an inactive component reducing the capacity of the alloy so a trade-off exists between high capacity and good cyclability by varying Ni content [197]. Mukaibo showed that electrodeposited Ni-Sn alloy with 62 at\% of Sn has a high capacity of $650 \mathrm{mAh} \mathrm{g}^{-1}$ after 70 cycles and very good reversibility [198]. Electrodeposition of $\mathrm{Ni}-\mathrm{Sn}$ anode has been successfully applied in microbatteries with complex electrode design [56,88]. $\mathrm{TiO}_{2}$ is an important functional oxide for dyesensitized solar cell application. The energy storage capability of $\mathrm{TiO}_{2}$ has also been thoroughly investigated [199]. Among various polymorphs, the rutile and anatase phases are thermodynamically the most stable. The rutile $\mathrm{TiO}_{2}$, first considered to be inactive [200], was later proved to be able to reversibly insert Li in its nanocrystalline phase [201]. This is because the Li diffusion in the rutile phase is highly anisotropic and diffusion in the ab-plane is very slow $[202,203]$. Anatase $\mathrm{TiO}_{2}$ has far more facile $\mathrm{Li}$ insertion therefore is more electrochemically active [204]. It reversibly uptakes $0.5 \mathrm{Li}$ and proceeds through a two-phase equilibrium, hence the voltage profile is characterized by a flat voltage plateau at about $1.8 \mathrm{~V}$ versus $\mathrm{Li} / \mathrm{Li}^{+}[205,206]$. Conformal deposition of $\mathrm{TiO}_{2}$ can be carried out using atomic layer deposition [37,207].

\subsection{Electrolytes}

Electrolyte systems are generally categorized into liquid 
electrolytes and solid electrolytes by the physical state at ambient condition. Liquid electrolyte refers to systems where lithium salts are dissolved in liquid organic (non-aqueous) solvents or aqueous solvents. It is still the most common electrolyte system in commercial LIBs. In many reports of microbatteries with nanostructured or 3D electrodes, liquid electrolytes are adopted since the focus is the design and electrochemical properties of a single electrode (half-cell). However, the use of solid electrolytes becomes more suitable as the dimensions (size) shrink. Compared to liquid electrolytes, solid electrolytes generally have greater dimensional stability, no leakage issues, and better thermal and electrochemical stability. Deposition of solid electrolytes enables the construction of all-solid-state microbatteries with complex architectures.

Solid electrolytes can be further categorized into inorganic/ ceramic electrolytes and polymer-based solid electrolytes. Relevant inorganic electrolyte systems include sulfides and oxides. As they are mostly rigid, the main application is in thin-film batteries [208]. The most prominent example is Lipon developed by Oak Ridge National Laboratory [25-27]. It is prepared by sputtering $\mathrm{Li}_{3} \mathrm{PO}_{4}$ in pure $\mathrm{N}_{2}$ so that $\mathrm{N}$ partially substitutes $\mathrm{O}$ to form an amorphous oxynitride. Nitrogen incorporation greatly enhances the ionic conductivity to about $1-2 \mu \mathrm{S} \mathrm{cm}^{-1}$ and improves the electrochemical stability. Most notably, Lipon has an electrochemical window of $0-5.5 \mathrm{~V}$ versus $\mathrm{Li} / \mathrm{Li}^{+}$, meaning it is stable in contact with metallic lithium. Lipon is widely applied in commercial thinfilm microbatteries due to its combination of favorable traits.

Polymer-based solid electrolytes fall into two families, the solid polymer electrolytes (SPE) and gel polymer electrolytes (GPE). They are mechanically more flexible than inorganic electrolytes, hence ideal for constructing flexible batteries. SPE are complexes formed by solvation of Li salts in polymer chains. Poly(ethylene oxide)
(PEO) is the most commonly used polymer and possesses a great ability to dissolve various lithium salts. No liquid components are present in this system so it is inherently safe. However, the ionic conductivity is fairly low $\left(10^{-8}\right.$ to $10^{-4} \mathrm{~S} \mathrm{~cm}^{-1}$ ) [209]. Adding nanoscale ceramic fillers has been proven beneficial to the conduction as well as mechanical properties. Conduction in SPE was initially regarded viable only in its glassy state, but the discovery of fast conduction in crystalline SPE discredited the assumption $[210,211]$. Use of SPE as solid electrolytes and separator layers in microbatteries has been successfully demonstrated [51,212]. GPE are composites of a liquid electrolyte solution and polymer matrix. Due to the presence of liquid electrolytes, the ionic conductivity of the system $\left(>10^{-3} \mathrm{~S} \mathrm{~cm}^{-1}\right)$ is much greater than other solid systems, only inferior to the liquid electrolytes. However, it also means the issues with liquid electrolytes (leakage, safety concern, degradation, etc.) still exist in GPE, only to a lesser extent. Common polymer matrix and electrolyte solutions are poly(vinylidene fluoride-hexafluoropropylene) (PVdF-HFP) and $\mathrm{LiPF}_{6}$ dissolved in ethylene carbonate, propylene carbonate (EC-PC). Both SPE and GPE can be prepared by conventional casting methods. Alternatively, they can also be prepared by electropolymerization where conformal coating of thin polymer electrolyte layers can be achieved with high precision $[47,213]$. Recently, in-situ preparation of UV-curable polymer electrolyte has gained popularity [50,214,215].

\section{Review of recent novel concepts and designs of lithium- based microbatteries}

\subsection{High-performance primary microbatteries}

Acoustic micro transmitters are the key components in the
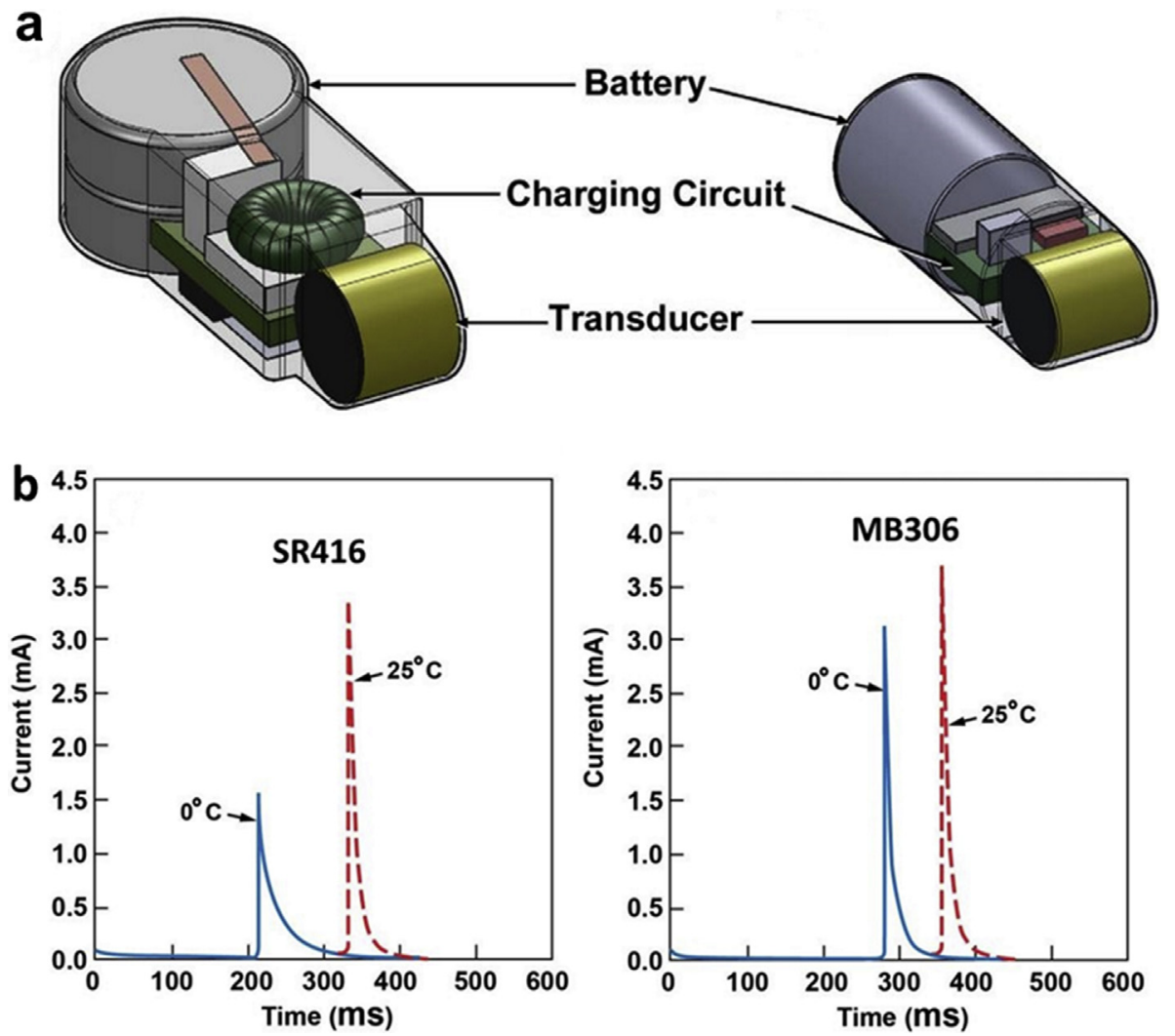

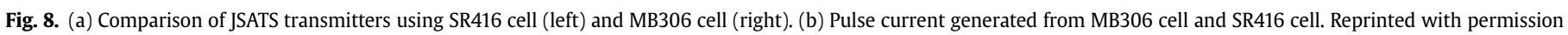
from Ref. [12]. 
JSATS [216] which is developed to observe and better understand the behavior of juvenile salmon passing through dams [217]. The operation conditions of micro transmitters require their energy storage devices to possess high capacity while supply high current pulses when needed. Two button cells SR416 adopted in the old design were heavy and bulky. To increase the specific capacity, a custom-made primary microbattery (MB306) employing the lithium/carbon fluoride $\left(\mathrm{Li} / \mathrm{CF}_{\mathrm{x}}\right)$ chemistry was designed by PNNL scientists (Fig. 8a). Carbon fluorides have the highest theoretical energy density but suffer from poor electronic conductivity and hence large polarization at a high rate. In order to decrease the internal resistance, the laminated cathode was pressed onto aluminum mesh which allows high loading; the jellyroll design was adopted, which greatly increased the total electrode area as compared to its button cell predecessor (SR416). As a result, the resistance associated with the electrode, electrolyte and current collectors of $\mathrm{Li} / \mathrm{CF}_{\mathrm{X}}$ batteries was much lower than that of SR416 cells and stable within the whole temperature range. The pulse current test (Fig. 8b) showed that the peak intensity of MB306 cells dropped by about $15 \%$ when temperature changes from $25^{\circ} \mathrm{C}$ to $0{ }^{\circ} \mathrm{C}$ whereas a 50\% drop was seen for SR416 cells. Most importantly, MB306 cells are much lighter and smaller than SR416 cells, allowing the transmitters to be injected. When tested using real JSATS transmitters at room temperature, MB306 powered transmitters have a longer service life than SR416 powered transmitters, thanks to the much improved energy density. This technology may have a big potential market as the flexible cell design allows scaling and downsizing for other applications including sensor packages and medical micro devices.

\section{2. $3 D$ printed microbatteries}

3D printing technology has attracted more and more attention, especially after the printers became commercially available in recent years. 3D solid objects of any desired shape can be produced which makes 3D printing a low-cost and flexible tool for producing 3D microbatteries as compared to other processes such as deposition and lithographic masking/etching. Sun et al. recently constructed working 3D printed microbatteries (3D-IMA) which have exceptionally high areal energy density and power density [34].

The batteries are based on $\mathrm{LiFePO}_{4}(\mathrm{LFP}) / \mathrm{Li}_{4} \mathrm{Ti}_{5} \mathrm{O}_{12}$ (LTO) chemistry. LTO is a well know zero strain anode and LFP has a relatively small volume variation of $2.2 \%$ during cycling. A key to the successful fabrication is optimizing the composition and rheological properties of the cathode and anode inks so they can flow smoothly through the $30 \mu \mathrm{m}$ cylindrical nozzle while maintaining good adhesion and structural integrity. The inks are printed onto an interdigitated substrate layer by layer to achieve an aspect ratio of about 0.8 (height over width). A final heating step at $600{ }^{\circ} \mathrm{C}$ removes organic and sinters the nanoparticles. SEM analysis (Fig. 9a) shows that the layers are well bonded and the annealed electrodes are have sufficient porosity for electrolyte penetration.

The electrochemical properties of the printed 8-layer and 16layer 3D-IMA were investigated. High rate tests suggest that the
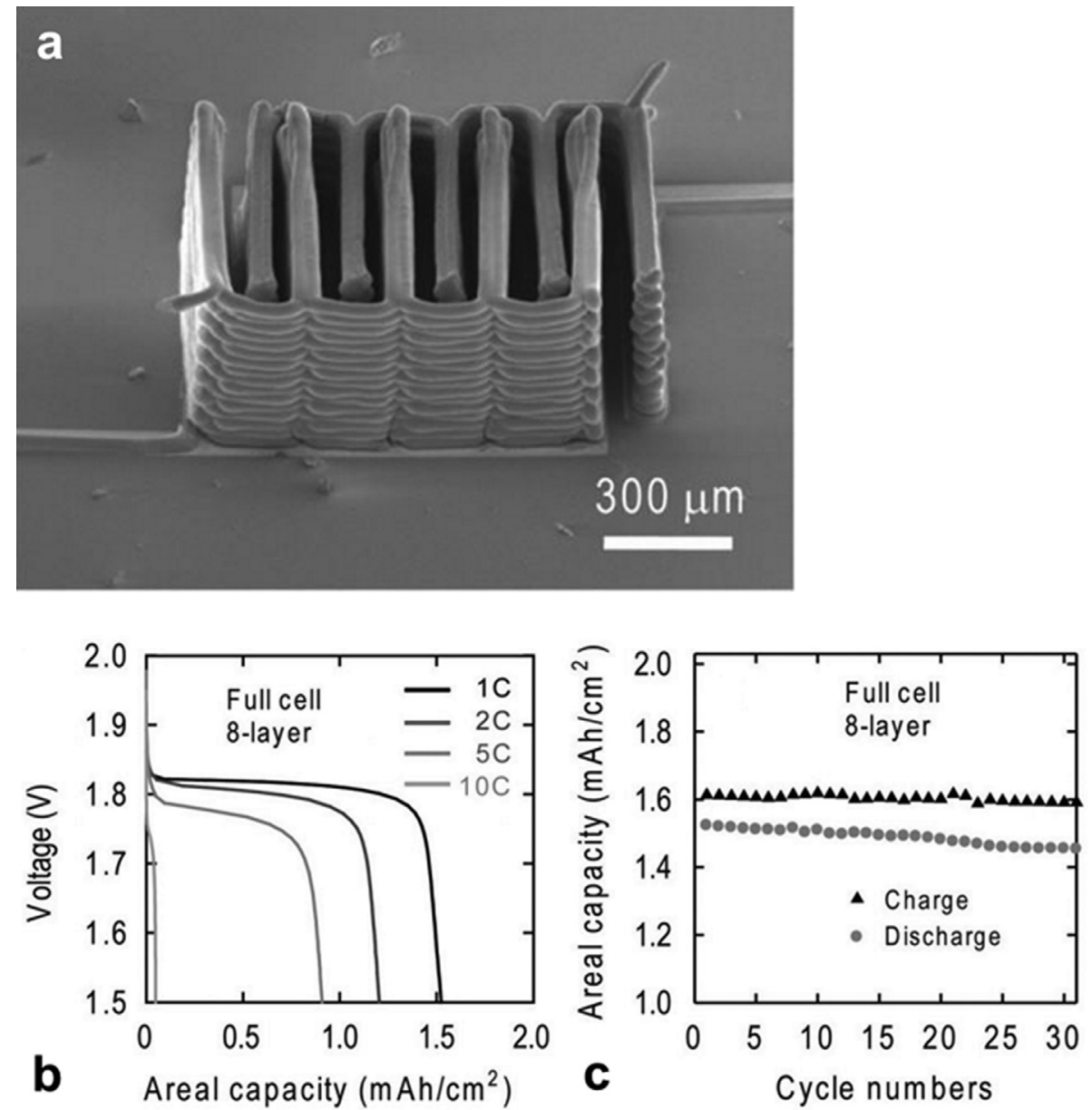

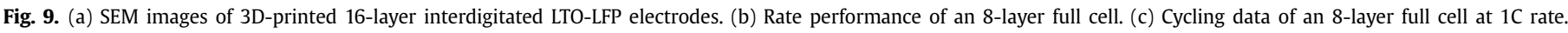
Reprinted with permission from Ref. [34]. 


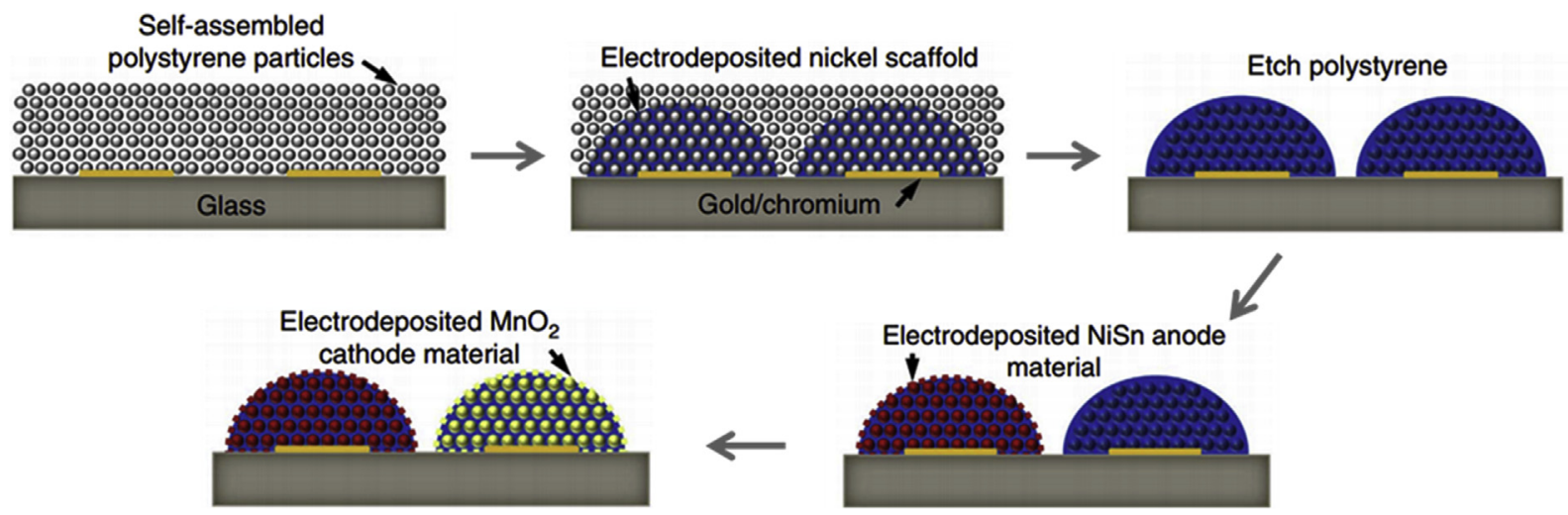

Fig. 10. Fabrication process of 3D microbattery with interdigitated nanoporous electrodes. Reproduced with permission from Ref. [36].

kinetics of the reaction is constrained by the height of the electrodes due to the poor electronic conduction of both cathode materials. In the full cell configuration, the 8-layer LTO-LFP battery delivers $\sim 1.5 \mathrm{mAh} \mathrm{cm}^{-2}$ at a stable working voltage of $1.8 \mathrm{~V}$ when discharged at 1C (Fig. 9b) and exhibits about 10\% capacity decay in 30 cycles (Fig. 9c). The authors attribute the good performance to the combination of high aspect ratio and small transport length. This 3D printing approach is easily transferable to other chemistries which may further increase the energy and power densities.

\subsection{D microbatteries with interdigitated nanoporous electrodes}

3D microbatteries face difficulty of packing high volume of electrode materials on a small scale without losing their power density. Pikul et al. designed a 3D microbattery from interdigitated bicontinuous nanoporous electrodes [36]. The battery has extremely high power density of $7.4 \mathrm{~mW} \mathrm{~cm}^{-2} \mu \mathrm{m}^{-1}$, comparable to supercapacitors, while maintaining similar energy densities to other microbatteries.

Fig. 10 illustrates the construction procedure of the microbattery. Firstly, a polystyrene scaffold was self-assembled on a glass substrate with interdigitated gold template and sintered to achieve the desired interconnected size. Porous nickel scaffolds with pore sizes of 330 or $500 \mathrm{~nm}$ were then electrodeposited to act as current collectors. The polystyrene scaffold was subsequently removed by toluene. The $\mathrm{Ni}-\mathrm{Sn}$ anode and $\mathrm{LiMnO}_{2}$ cathode were electrodeposited onto nickel scaffolds sequentially. The electrodeposition ensures conformal coating of $17-90 \mathrm{~nm}$ thick active materials onto porous current collector scaffolds. This electrode design provides short electron and ion transport lengths while still packing a high volume of active materials. The battery retains $28 \%$ of its low-rate capacity at a nearly $1000 \mathrm{C}$ rate, impressively. However, the battery loses about $5 \%$ of its energy after each cycle at a $1 \mathrm{C}$ rate, indicating much room for improvement. The authors attributed the capacity loss to SEI formation.

\subsection{Shape-conformable polymer electrolytes for $3 D$ microbatteries}

High power density and design flexibility can be achieved by 3D designs. Moreover, large volume expansion of high-capacity anode materials can be accommodated. However, fabrication of 3D electrodes faces challenges of preventing shorting between electrodes when liquid electrolytes are used. Kil et al. designed a shape conformable, flexible and imprintable gel polymer electrolyte and demonstrated its application for 3D electrodes [50]. The gel polymer electrolyte (GPE) is composed of UV curable ethoxylated trimethylolpropane triacrylate (ETPTA) monomers, high-boiling point liquid electrolytes and $\mathrm{Al}_{2} \mathrm{O}_{3}$ nanoparticles. The viscosity of the electrolyte is adjusted by the content of $\mathrm{Al}_{2} \mathrm{O}_{3}$ nanoparticles so no dripping occurs after printed and vertically tilted. This property ensures conformability on 3D electrodes. After the electrolyte was imprinted, a UV curing step was applied to promote cross-linking of the polymer matrix and to solidify the GPE (Fig. 11). The ionic conductivity of the GPE was measured to be more than $1 \mathrm{mS} \mathrm{cm} \mathrm{cm}^{-1}$ at room temperature. Cells with $\mathrm{LiCoO}_{2}$ cathode/GPE/Li anode showed high capacity and negligible capacity loss during cycling. In another cell, the conformable GPE was successfully formed on a 3D pillar structured $\mathrm{Si}$ anode. The initial charge capacity was $2680 \mathrm{mAh} \mathrm{g}^{-1}$ but the capacity faded quickly during cycling. In comparison, no meaningful capacity was observed for cells using

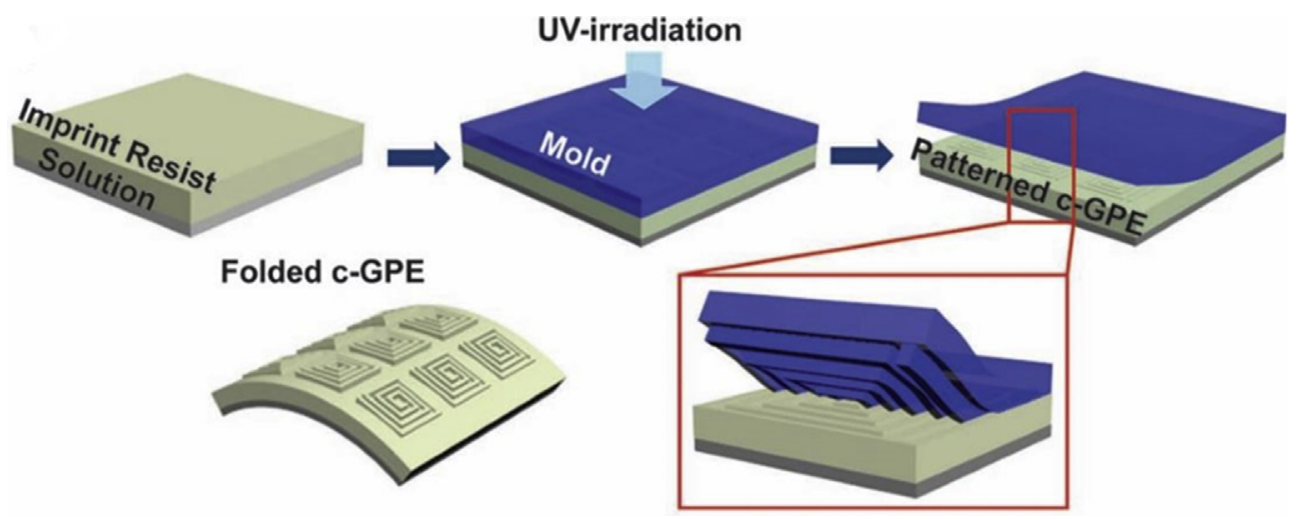

Fig. 11. Fabrication of UV-curable, shape-conformable gel polymer electrolyte. Reprinted with permission from Ref. [50]. 


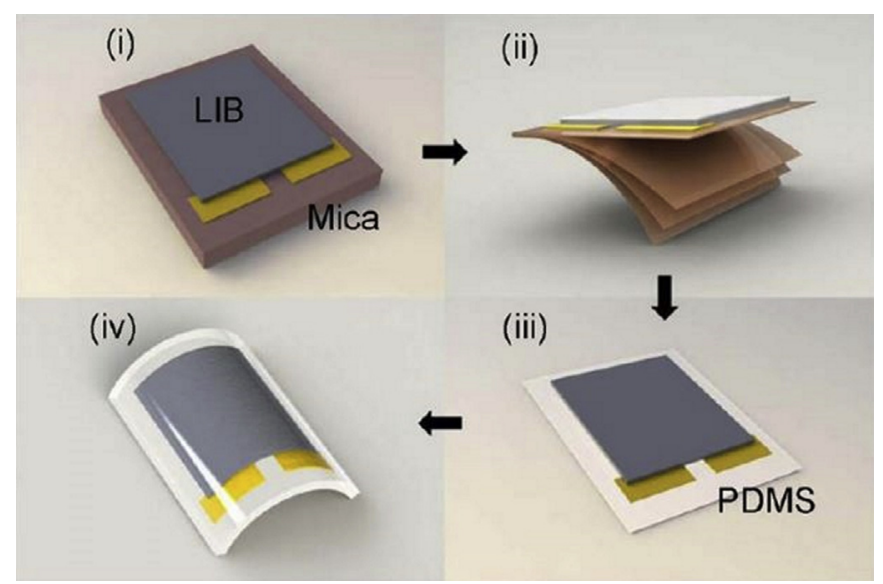

Fig. 12. Fabrication process of the bendable inorganic thin-film battery via a transfer approach. Reprinted with permission from Ref. [54].

non-optimized electrolyte, indicating the crucial role of GPE in enabling 3D Si anodes. This technology could be useful for the design of 3D microbatteries.

\subsection{Bendable thin-film batteries via a novel transfer approach}

Traditionally, thin-film, all-solid-state batteries are rigid since the layers of battery components are deposited on silicon or metal substrates. The crystallinity of electrode materials is crucial for the cell performance so high-temperature processes or post-annealing steps are required which makes the use of flexible plastic substrate improbable. Lee et al. developed a novel transfer approach with which bendable thin-film batteries were constructed [54].

The construction (Fig. 12) started with standard deposition procedure of $\mathrm{LiCOO}_{2} / \mathrm{Lipon} / \mathrm{Li}$ thin-film batteries on a brittle mica substrate. This type of thin-film battery was developed in the 1990s and proven extremely stable during cycling. Subsequently, the mica substrate was delaminated using a sticky tape. The success of the delamination step is attributed to the weakly-bonded layered structure of mica and further weakening of the bonding through annealing. The cell stacks were then sandwiched between two PDMS sheets to enhance the mechanical stability. The mechanical flexibility was tested and the effect of bending was evaluated by electrochemical testing. No damages were observed on the $18 \mathrm{~mm} \times 18 \mathrm{~mm}$ electrode with a bending radius of $3.1 \mathrm{~mm}$. The discharge capacity slightly decreased under bending conditions which can be explained by the positive relationship of charge transfer resistance and internal stresses. Nevertheless, the flexible cell with a bending radius of $3.1 \mathrm{~mm}$ has a capacity retention of $94.5 \%$ and nearly $100 \%$ Columbic efficiency after 100 cycles at a C/2 rate. The authors attributed the excellent mechanical robustness to the fact that the electrochemically active layers are located at a mechanically neutral plane. A prototype of all-in-one, fully-functional flexible LED system was fabricated for the first time demonstrating the practical use of the bendable batteries in flexible electronics.

\subsection{Cable batteries}

Conventional Li batteries with layered architecture cannot withstand external mechanical distortion so the shape of batteries is a limiting factor to the design of portable electronic devices. The rapid growth of flexible electronics such as OLED displays and wearable devices demands greater flexibility in their power sources. Recently, a cable-type lithium ion battery was developed by LG Chem, Ltd., which can sustain normal operation under bending or twisting conditions [56].

The fabrication procedure is shown in Fig. 13. Firstly, three strands of $\mathrm{Sn}-\mathrm{Ni}$-coated $\mathrm{Cu}$ wire were twisted together into bundles, which were then wound around a circular rod. The hollowhelix anode was formed by removing the rod. Separators, Al wires and $\mathrm{LiCoO}_{2}$ positive electrodes were then wound around the anode and sealed by heating a heat-shrinkable tube. Finally, a liquid electrolyte was injected into the hollow space between electrodes. The whole cell has an outer diameter of about $2 \mathrm{~mm}$ and design capacity of $1 \mathrm{mAh} \mathrm{cm}{ }^{-1}$. Three main design features give rise to the mechanical flexibility of the cell. 1) A flexible $\mathrm{Sn}-\mathrm{Ni}$ alloy anode was selected and $5 \mathrm{wt}$ \% Ni was employed as a result of tradeoffs between flexibility and cyclability. 2) The hollow-helix anode has a spring-like structure, which prevents shorting even under extreme

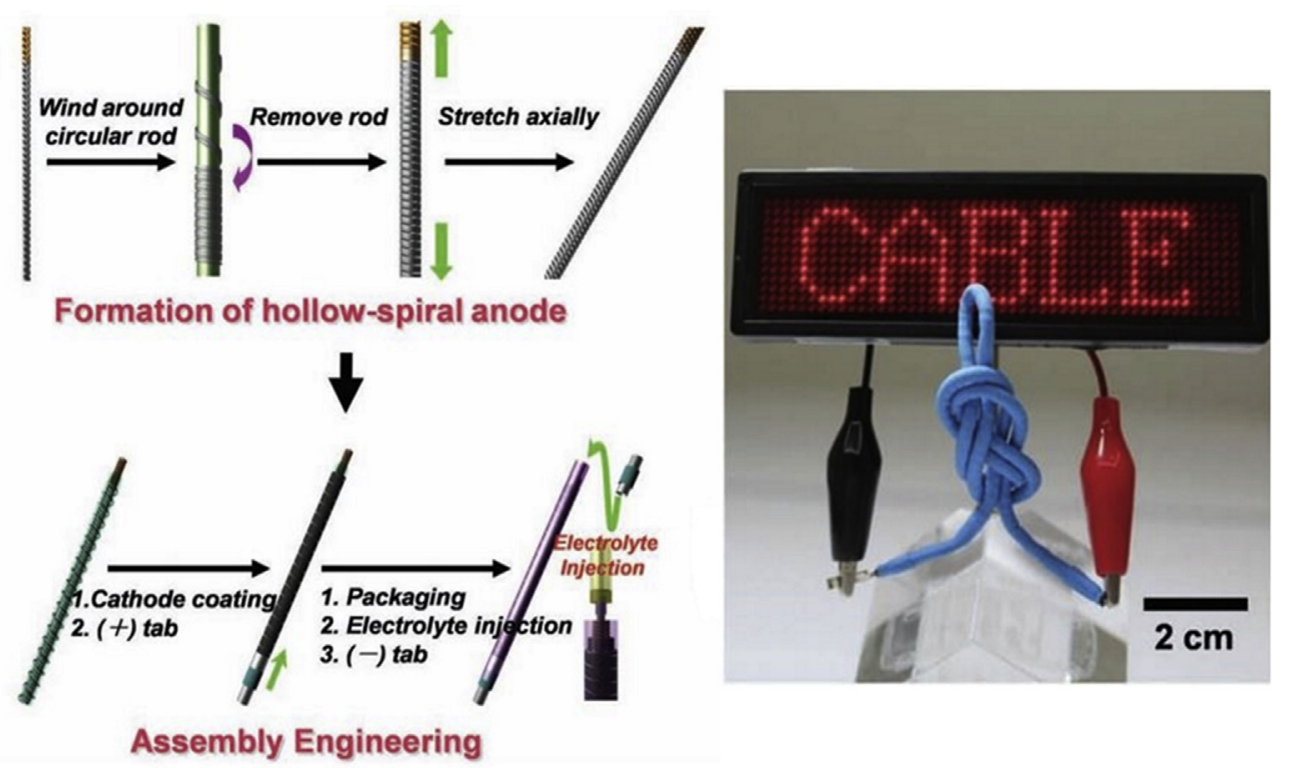

Fig. 13. Cable battery fabrication process. Reprinted with permission from Ref. [56]. 
deformation. 3) The heat-shrinkable tubes tightly constraints the cathodes and prevents crumbling of active materials and separation from current collectors.

Electrochemical tests showed that the cable battery delivered the designed capacity and had stable capacity retention at a C/10 rate. In comparison, the cell with a non-hollow anode had a much smaller capacity. This indicates that the hollow design greatly improves the accessibility of liquid electrolytes to active materials. The battery successfully supplies power to a LED screen under severe bending conditions with only a small variation of discharge characteristic observed. However, it was mentioned that there was a slight loss of capacity under bending and further mechanical testing such as fatigue behavior needs to be carried out to evaluate its effect on the electrochemical performance.

\section{Concluding remarks and future perspectives}

Lithium and lithium ion batteries are adopted in an extensive range of applications. The continuous downscaling of microelectronics, especially the rapid growth of MEMS devices, has created a large demand for high-performance energy storage devices on the millimeter scale or less. Microbatteries differ greatly from conventional cells regarding the architecture and material selections. The planar design adopted by traditional microbatteries limits areal power and energy densities. Research on lithium microbatteries has focused on innovative fabrication methods and novel cell designs in order to utilize the out-of-plane space and enhance areal power and energy densities. 3D Concepts such as electrodes with arrays of microrods synthesized by templating method and interdigitated electrodes have been proposed. There also has been a surge of interest in flexible (mechanically) design recently. The realization of these new concepts requires the identification of innovative packaging materials and appropriate selection of materials and fabrication methods. The future directions of microbattery development are towards further enhancement of energy/ power densities and applications in micro energy harvesting.

\section{Acknowledgment}

The study was funded by the U.S. Department of Energy Wind and Water Power Technologies Office and the U.S. Army Corps of Engineers, Portland District. JX and BL would like to thank the support from The Laboratory Directed Research and Development (LDRD) Program at PNNL for the work of solid state electrolyte. The study was conducted at Pacific Northwest National Laboratory, operated by Battelle for the U.S. Department of Energy.

\section{References}

[1] J. Liu, Adv. Funct. Mater. 23 (2013) 924-928.

[2] M.M. Thackeray, Prog. Solid State Ch 25 (1997) 1-71.

[3] Watanabe N., Fukuda M., US Patent, 3,536,532 (1970).

[4] E.S. Takeuchi, P. Piliero, J. Power Sources 21 (1987) 133-141.

[5] M.S. Whittingham, Chem. Rev. 104 (2004) 4271-4301.

[6] C.R. Yang, Y.Y. Wang, C.C. Wan, J. Power Sources 72 (1998) 66-70.

[7] K. Xu, Chem. Rev. 104 (2004) 4303-4417.

[8] J.M. Tarascon, M. Armand, Nature 414 (2001) 359-367.

[9] C.A. Mack, Ieee T Semicond. M. 24 (2011) 202-207.

[10] D.C. Bock, A.C. Marschilok, K.J. Takeuchi, E.S. Takeuchi, Electrochim Acta 84 (2012) 155-164

[11] A. Patil, V. Patil, D.W. Shin, J.W. Choi, D.S. Paik, S.J. Yoon, Mater. Res. Bull. 43 (2008) 1913-1942.

[12] H.H. Chen, S. Cartmell, Q. Wang, T. Lozano, Z.D. Deng, H.D. Li, X.L. Chen, Y. Yuan, M.E. Gross, T.J. Carlson, J. Xiao, Sci. Rep-Uk 4 (2014).

[13] http://news.panasonic.com/press/news/official.data/data.dir/2014/10/ en141003-2/en141003-2.html.

[14] K.A. Cook-Chennault, N. Thambi, A.M. Sastry, Smart Mater. Struct. 17 (2008).

[15] V. Etacheri, R. Marom, R. Elazari, G. Salitra, D. Aurbach, Energ. Environ. Sci. 4 (2011) 3243-3262.

[16] A. Manthiram, J. Phys. Chem. Lett. 2 (2011) 176-184.
[17] J.W. Long, B. Dunn, D.R. Rolison, H.S. White, Chem. Rev. 104 (2004) 4463-4492.

[18] J.F.M. Oudenhoven, L. Baggetto, P.H.L. Notten, Adv. Energy Mater. 1 (2011) $10-33$.

[19] M. Roberts, P. Johns, J. Owen, D. Brandell, K. Edstrom, G. El Enany, C. Guery, D. Golodnitsky, M. Lacey, C. Lecoeur, H. Mazor, E. Peled, E. Perre, M.M. Shaijumon, P. Simon, P.L. Taberna, J. Mater. Chem. 21 (2011) 9876-9890.

[20] B.J. Neudecker, N.J. Dudney, J.B. Bates, J. Electrochem Soc. 147 (2000) 517-523.

[21] B.J. Neudecker, W. Weppner, J. Electrochem Soc. 143 (1996) 2198-2203.

[22] H. Aono, E. Sugimoto, Y. Sadaoka, N. Imanaka, G. Adachi, J. Electrochem Soc. 137 (1990) 1023-1027.

[23] P.G. Bruce, A.R. West, J. Solid State Chem. 44 (1982) 354-365.

[24] H. Kawai, J. Kuwano, J. Electrochem Soc. 141 (1994) L78-L79.

[25] J.B. Bates, N.J. Dudney, G.R. Gruzalski, R.A. Zuhr, A. Choudhury, C.F. Luck, J.D. Robertson, J. Power Sources 43 (1993) 103-110.

[26] J.B. Bates, N.J. Dudney, G.R. Gruzalski, R.A. Zuhr, A. Choudhury, C.F. Luck, J.D. Robertson, Solid State Ionics 53 (1992) 647-654.

[27] J.B. Bates, N.J. Dudney, B. Neudecker, A. Ueda, C.D. Evans, Solid State Ionics 135 (2000) 33-45.

[28] N.J. Dudney, Interface 17 (2008) 44-49.

[29] http://industrial.panasonic.com/lecs/www-data/pdf2/ACI4000/ ACI4000CE17.pdf.

[30] http://nz.apexelex.com/specs/batteries/MEC200\%20Series\%20selector.pdf.

[31] http://nz.apexelex.com/specs/batteries/MEC200\%20Series\%20selector.pdf.

[32] http://html.alldatasheet.com/html-pdf/597023/PANASONICBATTERY/ ML421/1534/1/ML421.html.

[33] http://www.mouser.com/ds/2/315/crseries_datasheets_merged-462862.pdf.

[34] K. Sun, T.S. Wei, B.Y. Ahn, J.Y. Seo, S.J. Dillon, J.A. Lewis, Adv. Mater. 25 (2013) 4539-4543.

[35] W. Lai, C.K. Erdonmez, T.F. Marinis, C.K. Bjune, N.J. Dudney, F. Xu, R. Wartena, Y.M. Chiang, Adv. Mater. 22 (2010) E139-E144.

[36] J.H. Pikul, H.G. Zhang. J. Cho, P.V. Braun, W.P. King Nat. Commun, 4 (2013)

[37] S.K. Cheah, E. Perre, M. Rooth, M. Fondell, A. Harsta, L. Nyholm, M. Boman, T. Gustafsson, J. Lu, P. Simon, K. Edstrom, Nano Lett. 9 (2009) 3230-3233.

[38] C.R. Martin, Chem. Mater. 8 (1996) 1739-1746.

[39] L. Taberna, S. Mitra, P. Poizot, P. Simon, J.M. Tarascon, Nat. Mater. 5 (2006) $567-573$

[40] J.C. Hulteen, C.R. Martin, J. Mater. Chem. 7 (1997) 1075-1087.

[41] P.H.L. Notten, F. Roozeboom, R.A.H. Niessen, L. Baggetto, Adv. Mater. 19 (2007) 4564-4567.

[42] D. Tonti, M.J. Torralvo, E. Enciso, I. Sobrados, J. Sanz, Chem. Mater. 20 (2008) 4783-4790.

[43] R. Kostecki, X. Song, K. Kinoshita, Electrochem Solid St. 5 (2002) E29-E31.

[44] F. Chamran, Y. Yeh, H.S. Min, B. Dunn, C.J. Kim, J. Microelectromech S 16 (2007) 844-852.

[45] H.S. Min, B.Y. Park, L. Taherabadi, C.L. Wang, Y. Yeh, R. Zaouk, M.J. Madou, B. Dunn, J Power Sources 178 (2008) 795-800.

[46] H. Kim, R.C.Y. Auyeung, S.H. Lee, A.L. Huston, A. Pique, J. Phys. D. Appl. Phys. 43 (2010).

[47] C.P. Rhodes, J.W. Long, M.S. Doescher, B.M. Dening, D.R. Rolison, J. Non-Cryst Solids 350 (2004) 73-79.

[48] S.H. Liu, Z.Y. Wang, C. Yu, H.B. Wu, G. Wang, Q. Dong, J.S. Qiu, A. Eychmuller, X.W. Lou, Adv, Mater. 25 (2013) 3462-3467.

[49] J.Z. Wang, S.L. Chou, J. Chen, S.Y. Chew, G.X. Wang, K. Konstantinov, J. Wu, S.X. Dou, H.K. Liu, Electrochem Commun. 10 (2008) 1781-1784.

[50] E.H. Kil, K.H. Choi, H.J. Ha, S. Xu, J.A. Rogers, M.R. Kim, Y.G. Lee, K.M. Kim, K.Y. Cho, S.Y. Lee, Adv. Mater. 25 (2013) 1395-1400.

[51] Y. Liu, S. Gorgutsa, C. Santato, M. Skorobogatiy, J. Electrochem Soc. 159 (2012) A349-A356.

[52] H. Gwon, H.S. Kim, K.U. Lee, D.H. Seo, Y.C. Park, Y.S. Lee, B.T. Ahn, K. Kang, Energ. Environ. Sci. 4 (2011) 1277-1283.

[53] N. Li, Z.P. Chen, W.C. Ren, F. Li, H.M. Cheng, P Natl. Acad. Sci. U. S. A. 109 (2012) 17360-17365

[54] M. Koo, K.I. Park, S.H. Lee, M. Suh, D.Y. Jeon, J.W. Choi, K. Kang, K.J. Lee, Nano Lett. 12 (2012) 4810-4816.

[55] S. Xu, Y.H. Zhang, J. Cho, J. Lee, X. Huang, L. Jia, J.A. Fan, Y.W. Su, J. Su, H.G. Zhang, H.Y. Cheng, B.W. Lu, C.J. Yu, C. Chuang, T.I. Kim, T. Song, K. Shigeta, S. Kang, C. Dagdeviren, I. Petrov, P.V. Braun, Y.G. Huang, U. Paik, J.A. Rogers, Nat. Commun. 4 (2013).

[56] Y.H. Kwon, S.W. Woo, H.R. Jung, H.K. Yu, K. Kim, B.H. Oh, S. Ahn, S.Y. Lee, S.W. Song, J. Cho, H.C. Shin, J.Y. Kim, Adv. Mater. 24 (2012) 5192-5197.

[57] M.M. Thackeray, M.H. Rossouw, A. Dekock, A.P. Delaharpe, R.J. Gummow, K. Pearce, D.C. Liles, J. Power Sources 43 (1993) 289-300.

[58] T. Ohzuku, M. Kitagawa, T. Hirai, J. Electrochem Soc. 137 (1990) 769-775.

[59] R.J. Gummow, A. Dekock, M.M. Thackeray, Solid State Ionics 69 (1994) 59-67.

[60] M.M. Thackeray, A. Dekock, M.H. Rossouw, D. Liles, R. Bittihn, D. Hoge, J. Electrochem Soc. 139 (1992) 363-366.

[61] F. Lubin, A. Lecerf, M. Broussely, J. Labat, J. Power Sources 34 (1991) $161-173$.

[62] M.A. Humbert, P. Biensan, M. Broussely, A. Lecerf, A. Dolle, H. Ladhily, J. Power Sources 44 (1993) 681-687.

[63] M.H. Rossouw, D.C. Liles, M.M. Thackeray, W.I.F. David, S. Hull, Mater. Res. 
Bull. 27 (1992) 221-230.

[64] C.S. Johnson, M.F. Mansuetto, M.M. Thackeray, Y. Shao-Horn, S.A. Hackney, J. Electrochem Soc. 144 (1997) 2279-2283.

[65] H. Ikeda, T. Saito, H. Tamura, Manganese Dioxide Symposium, 1975, p. 384.

[66] D. Linden, T.B. Reddy, Handbook of Batteries, third ed., McGraw-Hill, New York, 2002.

[67] H. Ikeda, M. Hara, S. Narukawa, in: Proc. 28th Power Sources Symp, 1978, p. 210.

[68] Ikeda H., Hara M., Narukawa S., US Patent, 4,133,856 (1979).

[69] P.M. Dewolff, Acta Crystallogr. 12 (1959) 341.

[70] J.B. Fernandes, B.D. Desai, V.N.K. Dalal, J. Power Sources 15 (1985) 209-237.

[71] M.M. Thackeray, A. Dekock, L.A. Depicciotto, G. Pistoia, J. Power Sources 26 (1989) 355-363.

[72] G. Pistoia, J. Electrochem Soc. 129 (1982) 1861-1865.

[73] J.C. Nardi, J. Electrochem Soc. 132 (1985) 1787-1791.

[74] T. Ohzuku, M. Kitagawa, T. Hirai, J. Electrochem Soc. 137 (1990) 40-46.

[75] T. Ohzuku, M. Kitagawa, T. Hirai, J. Electrochem Soc. 136 (1989) 3169-3174.

[76] Y. Shao-Horn, S.A. Hackney, B.C. Cornilsen, J. Electrochem Soc. 144 (1997) 3147-3153.

[77] M.S. Park, W.Y. Yoon, J. Power Sources 114 (2003) 237-243.

[78] A. Pendashteh, M.F. Mousavi, M.A. Kiani, S.H. Kazemi, M.S. Rahmanifar, J. Iran. Chem. Soc. 9 (2012) 389-395.

[79] F.Y. Cheng, J.Z. Zhao, W. Song, C.S. Li, H. Ma, J. Chen, P.W. Shen, Inorg. Chem. 45 (2006) 2038-2044.

[80] V. Subramanian, H.W. Zhu, R. Vajtai, P.M. Ajayan, B.Q. Wei, J. Phys. Chem. B 109 (2005) 20207-20214.

[81] G.H. Yu, L.B. Hu, M. Vosgueritchian, H.L. Wang, X. Xie, J.R. McDonough, X. Cui, Y. Cui, Z.N. Bao, Nano Lett. 11 (2011) 2905-2911.

[82] Z.S. Wu, W.C. Ren, D.W. Wang, F. Li, B.L. Liu, H.M. Cheng, ACS Nano 4 (2010) 5835-5842.

[83] P. Ragupathy, D.H. Park, G. Campet, H.N. Vasan, S.J. Hwang, J.H. Choy, N. Munichandraiah, J. Phys. Chem. C 113 (2009) 6303-6309.

[84] J.G. Wang, Y. Yang, Z.H. Huang, F.Y. Kang, J. Power Sources 204 (2012) 236-243.

[85] A.M. Hashem, H.M. Abuzeid, A.E. Abdel-Ghany, A. Mauger, K. Zaghib, C.M. Julien, J. Power Sources 202 (2012) 291-298.

[86] P. Johns, M. Roberts, J. Owen, J. Mater. Chem. 21 (2011) 10153-10159.

[87] J.H. Kim, T. Ayalasomayajula, V. Gona, D. Choi, J. Power Sources 183 (2008) 366-369.

[88] J.H. Pikul, P.V. Braun, W.P. King, J. Phys. Conf. Ser. 476 (2013).

[89] H.F. Hunger, J.E. Ellison, J. Electrochem Soc. 122 (1975) 1288-1291.

[90] M.R. Suchanski, J. Electrochem Soc. 132 (1985) 2059-2063.

[91] S.S. Zhang, D. Foster, J. Wolfenstine, J. Read, J. Power Sources 187 (2009) 233-237.

[92] H. Touhara, K. Kadono, Y. Fujii, N. Watanabe, Z Anorg. Allg. Chem. 544 (1987) $7-20$.

[93] J. Read, E. Collins, B. Piekarski, S. Zhang, J. Electrochem Soc. 158 (2011) A504-A510.

[94] Y. Kita, N. Watanabe, Y. Fujii, J. Am. Chem. Soc. 101 (1979) 3832-3841.

[95] D.E. Palin, K.D. Wadsworth, Nature 162 (1948) 925-926.

[96] W. Rüdorff, G. Rüdorff, Z. Anorg. Chem (1947) 281-296.

[97] P. Hany, R. Yazami, A. Hamwi, J. Power Sources 68 (1997) 708-710.

[98] T. Mallouk, N. Bartlett, J. Chem. Soc. Chem. Comm. (1983) 103-105.

[99] R. Yazami, A. Hamwi, Solid State Ionics 28 (1988) 1756-1761.

[100] T. Nakajima, N. Watanabe, I. Kameda, M. Endo, Carbon 24 (1986) 343-351.

[101] N. Watanabe, Solid State Ionics 1 (1980) 87-110.

[102] V.N. Mitkin, I.P. Asanov, L.N. Mazalov, J. Struct. Chem. 43 (2002) 843-855.

[103] C. Delabarre, M. Dubois, J. Giraudet, K. Guerin, A. Hamwi, Carbon 44 (2006) 2543-2548.

[104] M. Dubois, K. Guerin, J.P. Pinheiro, Z. Fawal, F. Masin, A. Hamwi, Carbon 42 (2004) 1931-1940.

[105] K. Guerin, R. Yazami, A. Hamwi, Electrochem Solid St. 7 (2004) A159-A162.

[106] S.S. Zhang, D. Foster, J. Read, J. Power Sources 191 (2009) 648-652.

[107] P.F. Fulvio, S.S. Brown, J. Adcock, R.T. Mayes, B.K. Guo, X.G. Sun, S.M. Mahurin, G.M. Veith, S. Dai, Chem. Mater. 23 (2011) 4420-4427.

[108] J. Giraudet, C. Delabarre, K. Guerin, M. Dubois, F. Masin, A. Hamwi, J. Power Sources 158 (2006) 1365-1372.

[109] A. Hamwi, H. Alvergnat, S. Bonnamy, F. Beguin, Carbon 35 (1997) 723-728.

[110] R. Yazami, A. Hamwi, K. Guerin, Y. Ozawa, M. Dubois, J. Giraudet, F. Masin, Electrochem Commun. 9 (2007) 1850-1855.

[111] F. Okino, S. Yajima, S. Suganuma, R. Mitsumoto, K. Seki, H. Touhara, Synth. Met. 70 (1995) 1447-1448.

[112] N. Liu, H. Touhara, Y. Morio, D. Komichi, F. Okino, S. Kawasaki, J. Electrochem Soc. 143 (1996) L214-L217.

[113] Y. Matsuo, T. Nakajima, Electrochim Acta 41 (1996) 15-19.

[114] P. Meduri, H.H. Chen, J. Xiao, J.J. Martinez, T. Carlson, J.G. Zhang, Z.D. Deng, J. Mater. Chem. A 1 (2013) 7866-7869.

[115] P. Lam, R. Yazami, J. Power Sources 153 (2006) 354-359.

[116] L. Znaidi, N. Baffier, M. Huber, Mater. Res. Bull. 24 (1989) 1501-1514.

[117] E. Wenda, J. Therm. Anal. Calorim. 30 (1985) 879-887.

[118] P. Rozier, J.M. Savariault, J. Galy, J. Solid State Chem. 122 (1996) 303-308.

[119] K.J. Takeuchi, A.C. Marschilok, S.M. Davis, R.A. Leising, E.S. Takeuchi, Coord. Chem. Rev. 219 (2001) 283-310.

[120] Liang C.C., Bolster E., Murphy R.M., US Patent, 4,310,609 (1982).

[121] E.S. Takeuchi, in: Proceedings, 6th Annual Battery Conference on Application and Advances, 1991. Long Beach, CA.

[122] E.S. Takeuchi, W.C. Thiebolt, J. Electrochem Soc. 135 (1988) 2691-2694.

[123] G.M. Bergman, S.J. Ebel, E.S. Takeuchi, P. Keister, J. Power Sources 20 (1987) 179-185.

[124] Crep A.M.I, US Patent, 5,221,453 (1990).

[125] R.A. Leising, E.S. Takeuchi, Chem. Mater. 5 (1993) 738-742.

[126] H.W. Zandbergen, A.M. Crespi, P.M. Skarstad, J.F. Vente, J. Solid State Chem. 110 (1994) 167-175.

[127] M. Onoda, K. Kanbe, J. Phys-Condens Mat. 13 (2001) 6675-6685.

[128] W.C. Thiebolt, E.S. Takeuchi, J. Electrochem Soc. 134 (1987) C403.

[129] R.P. Ramasamy, C. Feger, T. Strange, B.N. Popov, J. Appl. Electrochem 36 (2006) 487-497.

[130] F. Garciaalvarado, J.M. Tarascon, Solid State Ionics 73 (1994) 247-254.

[131] R.A. Leising, W.C. Thiebolt, E.S. Takeuchi, Inorg. Chem. 33 (1994) 5733-5740.

[132] F. Garciaalvarado, J.M. Tarascon, B. Wilkens, J. Electrochem Soc. 139 (1992) $3206-3214$

[133] K. West, A.M. Crespi, J. Power Sources 54 (1995) 334-337.

[134] F. Sauvage, V. Bodenez, J.M. Tarascon, K.R. Poeppelmeier, J. Am. Chem. Soc 132 (2010) 6778-6782.

[135] Y.Z. Wu, P.N. Zhu, X. Zhao, M.V. Reddy, S.J. Peng, B.V.R. Chowdari, S. Ramakrishna, J. Mater. Chem. A 1 (2013) 852-859.

[136] C. Arbizzani, S. Beninati, L. Damen, M. Mastragostino, Solid State Ionics 178 (2007) 393-398

[137] X.Y. Cao, L.L. Xie, H. Zhan, Y.H. Zhou, Inorg. Mater. 44 (2008) 886-889.

[138] J.G. Xie, X.Y. Cao, J.X. Li, H. Zhan, Y.Y. Xia, Y.H. Zhou, Ultrason. Sonochem 12 (2005) 289-293.

[139] X.Y. Cao, H. Zhan, J.G. Xie, Y.H. Zhou, Mater. Lett. 60 (2006) 435-438.

[140] H. Gan, R.S. Rubino, E.S. Takeuchi, J. Power Sources 146 (2005) 101-106.

[141] K. Chen, D.R. Merritt, W.G. Howard, C.L. Schmidt, P.A. Skarstad, J. Power Sources 162 (2006) 837-840.

[142] K. Ozawa, Solid State Ionics 69 (1994) 212-221.

[143] E. Antolini, Solid State Ionics 170 (2004) 159-171.

[144] R.J. Gummow, M.M. Thackeray, W.I.F. David, S. Hull, Mater. Res. Bull. 27 (1992) 327-337.

[145] B. Garcia, J. Farcy, J.P. PereiraRamos, N. Baffier, J. Electrochem Soc. 144 (1997) 1179-1184.

[146] H.J. Orman, P.J. Wiseman, Acta Crystallogr. C 40 (1984) 12-14.

[147] K. Mizushima, P.C. Jones, P.J. Wiseman, J.B. Goodenough, Mater. Res. Bull. 15 (1980) 783-789.

[148] T. Ohzuku, A. Ueda, J. Electrochem Soc. 141 (1994) 2972-2977.

[149] J.N. Reimers, J.R. Dahn, J. Electrochem Soc. 139 (1992) 2091-2097.

[150] J. Cho, Y.J. Kim, T.J. Kim, B. Park, Angew. Chem. Int. Ed. 40 (2001) 3471-3473.

[151] J. Cho, Y.J. Kim, B. Park, Chem. Mater. 12 (2000) 3788-3791.

[152] D. Aurbach, B. Markovsky, A. Rodkin, E. Levi, Y.S. Cohen, H.J. Kim, M. Schmidt, Electrochim Acta 47 (2002) 4291-4306.

[153] N. Imanishi, M. Fujiyoshi, Y. Takeda, O. Yamamoto, M. Tabuchi, Solid State Ionics 118 (1999) 121-128.

[154] M. Menetrier, I. Saadoune, S. Levasseur, C. Delmas, J. Mater. Chem. 9 (1999) $1135-1140$

[155] M.G.S.R. Thomas, P.G. Bruce, J.B. Goodenough, Solid State Ionics 18-9 (1986) 794-798.

[156] J.B. Bates, N.J. Dudney, B.J. Neudecker, F.X. Hart, H.P. Jun, S.A. Hackney, J. Electrochem Soc. 147 (2000) 59-70.

[157] J. Xie, N. Imanishi, T. Matsumura, A. Hirano, Y. Takeda, O. Yamamoto, Solid State Ionics 179 (2008) 362-370.

[158] B. Wang, J.B. Bates, F.X. Hart, B.C. Sales, R.A. Zuhr, J.D. Robertson, J. Electrochem Soc. 143 (1996) 3203-3213.

[159] K.A. Striebel, C.Z. Deng, S.J. Wen, E.J. Cairns, J. Electrochem Soc. 143 (1996) $1821-1827$.

[160] S. Ohta, T. Kobayashi, J. Seki, T. Asaoka, J. Power Sources 202 (2012) $332-335$.

[161] J.F.M. Oudenhoven, T, van Dongen, R.A.H. Niessen, M.H.J.M. de Croon, P.H.L. Notten, J. Electrochem Soc. 156 (2009) D169-D174.

[162] K.S. Han, S.W. Song, H. Fujita, M. Yoshimura, E.J. Cairns, S.H. Chang, J. Am. Ceram. Soc. 85 (2002) 2444-2448.

[163] S.W. Song, K.S. Han, M. Yoshimura, J. Am. Ceram. Soc. 83 (2000) 2839-2844.

[164] Y.H. Rho, K. Kanamura, T. Umegaki, J. Electrochem Soc. 150 (2003) A107-A111

[165] H. Kim, J. Proell, R. Kohler, W. Pfleging, A. Pique, J. Laser Micro Nanoen 7 (2012) 320-325.

[166] M.M. Thackeray, W.I.F. David, P.G. Bruce, J.B. Goodenough, Mater. Res. Bull. 18 (1983) 461-472.

[167] M.M. Thackeray, P.J. Johnson, L.A. Depicciotto, P.G. Bruce, J.B. Goodenough, Mater. Res. Bull. 19 (1984) 179-187.

[168] J.M. Tarascon, E. Wang, F.K. Shokoohi, W.R. Mckinnon, S. Colson, J. Electrochem Soc. 138 (1991) 2859-2864.

[169] J.M. Tarascon, F. Coowar, G. Amatuci, F.K. Shokoohi, D.G. Guyomard, J. Power Sources 54 (1995) 103-108.

[170] Y.Y. Xia, M. Yoshio, J. Electrochem Soc. 144 (1997) 4186-4194.

[171] G. Amatucci, J.M. Tarascon, J. Electrochem Soc. 149 (2002) K31-K46.

[172] F. Jiao, J.L. Bao, A.H. Hill, P.G. Bruce, Angew. Chem. Int. Ed. 47 (2008) 9711-9716.

[173] W. Tang, Y.Y. Hou, F.X. Wang, L.L. Liu, Y.P. Wu, K. Zhu, Nano Lett. 13 (2013) 2036-2040

[174] M. Nishizawa, T. Uchiyama, K. Dokko, K. Yamada, T. Matsue, I. Uchida 
B Chem. Soc. Jpn. 71 (1998) 2011-2015.

[175] C. Julien, E. Haro-Poniatowski, M.A. Camacho-Lopez, L. Escobar-Alarcon, J. Jimenez-Jarquin, Mat. Sci. Eng. B-Solid 72 (2000) 36-46.

[176] Y.J. Park, J.G. Kim, M.K. Kim, H.T. Chung, W.S. Um, M.H. Kim, H.G. Kim, J. Power Sources 76 (1998) 41-47.

[177] F.K. Shokoohi, J.M. Tarascon, B.J. Wilkens, D. Guyomard, C.C. Chang, J. Electrochem Soc. 139 (1992) 1845-1849.

[178] F.K. Shokoohi, J.M. Tarascon, B.J. Wilkens, Appl. Phys. Lett. 59 (1991) $1260-1262$.

[179] B.J. Hwang, C.Y. Wang, M.Y. Cheng, R. Santhanam, J. Phys. Chem. C 113 (2009) 11373-11380.

[180] K.L. Lee, J.Y. Jung, S.W. Lee, H.S. Moon, J.W. Park, J. Power Sources 130 (2004) $241-246$

[181] K.H. Hwang, S.H. Lee, S.K. Joo, J. Electrochem Soc. 141 (1994) 3296-3299.

[182] Y.S. Park, S.H. Lee, B.I. Lee, S.K. Joo, Electrochem Solid St. 2 (1999) 58-59.

[183] G.R. Goward, N.J. Taylor, D.C.S. Souza, L.F. Nazar, J. Alloy Compd. 329 (2001) $82-91$.

[184] M.N. Obrovac, L. Christensen, Electrochem Solid St. 7 (2004) A93-A96.

[185] J.P. Maranchi, A.F. Hepp, P.N. Kumta, Electrochem Solid St. 6 (2003) A198-A201.

[186] C.K. Chan, H.L. Peng, G. Liu, K. Mcllwrath, X.F. Zhang, R.A. Huggins, Y. Cui, Nat. Nanotechnol. 3 (2008) 31-35.

[187] J.R. Szczech, S. Jin, Energ. Environ. Sci. 4 (2011) 56-72.

[188] J. Cho, J. Mater. Chem. 20 (2010) 4009-4014.

[189] A. Magasinski, P. Dixon, B. Hertzberg, A. Kvit, J. Ayala, G. Yushin, Nat. Mater. 9 (2010) 353-358.

[190] T. Ohzuku, A. Ueda, N. Yamamoto, J. Electrochem Soc. 142 (1995) $1431-1435$

[191] K.M. Colbow, J.R. Dahn, R.R. Haering, J. Power Sources 26 (1989) 397-402.

[192] Y.J. Hao, Q.Y. Lai, D.Q. Liu, Z.U. Xu, X.Y. Ji, Mater. Chem. Phys. 94 (2005) $382-387$.

[193] Y.J. Hao, Q.Y. Lai, J.Z. Lu, H.L. Wang, Y.D. Chen, X.Y. Ji, J. Power Sources 158 (2006) 1358-1364.

[194] C.M. Shen, X.G. Zhang, Y.K. Zhou, H.L. Li, Mater. Chem. Phys. 78 (2003) 437-441.

[195] J.Q. Deng, Z.G. Lu, I. Belharouak, K. Amine, C.Y. Chung, J. Power Sources 193 (2009) 816-821.

[196] C.L. Wang, Y.C. Liao, F.C. Hsu, N.H. Tai, M.K. Wua, J. Electrochem Soc. 152
(2005) A653-A657

[197] J. Hassoun, S. Panero, B. Scrosati, J. Power Sources 160 (2006) 1336-1341.

[198] H. Mukaibo, T. Sumi, T. Yokoshima, T. Momma, T. Osaka, Electrochem Solid St. 6 (2003) A218-A220.

[199] Z.G. Yang, D. Choi, S. Kerisit, K.M. Rosso, D.H. Wang, J. Zhang, G. Graff, J. Liu, J. Power Sources 192 (2009) 588-598.

[200] B. Zachauchristiansen, K. West, T. Jacobsen, S. Atlung, Solid State Ionics 28 (1988) 1176-1182.

[201] Y.S. Hu, L. Kienle, Y.G. Guo, J. Maier, Adv. Mater. 18 (2006) 1421-1426.

[202] M.V. Koudraichova, N.M. Harrison, S.W. de Leeuw, Solid State Ionics 157 (2003) 35-38.

[203] O.W. Johnson, Phys. Rev. a-Gen Phys. 136 (1964) A284-A290.

[204] M. Wagemaker, A.A. van Well, G.J. Kearley, F.M. Mulder, Solid State Ionics 175 (2004) 191-193.

[205] T. Ohzuku, T. Kodama, T. Hirai, J. Power Sources 14 (1985) 153-166.

[206] M. Wagemaker, R. van de Krol, A.P.M. Kentgens, A.A. van Well, F.M. Mulder, J. Am. Chem. Soc. 123 (2001) 11454-11461.

[207] W. Wang, M. Tian, A. Abdulagatov, S.M. George, Y.C. Lee, R.G. Yang, Nano Lett. 12 (2012) 655-660.

[208] E. Quartarone, P. Mustarelli, Chem. Soc. Rev. 40 (2011) 2525-2540.

[209] J.W. Fergus, J. Power Sources 195 (2010) 4554-4569.

[210] A.M. Christie, S.J. Lilley, E. Staunton, Y.G. Andreev, P.G. Bruce, Nature 433 (2005) 50-53.

[211] Z. Gadjourova, Y.G. Andreev, D.P. Tunstall, P.G. Bruce, Nature 412 (2001) $520-523$

[212] H. Nakano, K. Dokko, J.I. Sugaya, T. Yasukawa, T. Matsue, K. Kanamura, Electrochem Commun. 9 (2007) 2013-2017.

[213] G. El-Enany, M.J. Lacey, P.A. Johns, J.R. Owen, Electrochem Commun. 11 (2009) 2320-2323.

[214] S.H. Kim, K.H. Choi, S.J. Cho, J.S. Park, K.Y. Cho, C.K. Lee, S.B. Lee, J.K. Shim, S.Y. Lee, J. Mater. Chem. A 2 (2014) 10854-10861.

[215] S.H. Kim, S.J. Jeon, G.R. Yi, C.J. Heo, J.H. Choi, S.M. Yang, Adv. Mater. 20 (2008) $1649-1655$.

[216] G.A. McMichael, M.B. Eppard, T.J. Carlson, J.A. Carter, B.D. Ebberts, R.S. Brown, M. Weiland, G.R. Ploskey, R.A. Harnish, Z.D. Deng, Fisheries 35 (2010) 9-22.

[217] Z. Deng, T.Z. Carlson, H. Li, J. Xiao, M.J. Myjak, J. Lu, J.J. Martinez, C.M. Woodley, M.A. Weiland, M.B. Eppard, Sci. Rep. 5 (2015) 8111. 